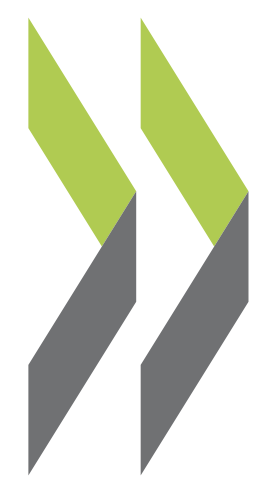

OECD Working Papers on International Investment 2019/03

Drivers of divestment decisions of multinational enterprises - A crosscountry firm-level perspective

\section{Maria Borga,}

Perla Ibarlucea Flores, Monika Sztajerowska 


\section{OECD WORKING PAPERS ON INTERNATIONAL INVESTMENT}

OECD Working Papers should not be reported as representing the official views of the OECD or of its member countries. The opinions expressed and arguments employed are those of the authors. Working Papers describe preliminary results or research in progress by the author(s) and are published to stimulate discussion on a broad range of issues on which the OECD works. Comments on Working Papers are welcomed, and may be sent to investment@oecd.orgor the Investment Division, Directorate for Financial and Enterprise Affairs, OECD, 2 rue André Pascal, 75775 Paris Cedex 16, France.

\section{OECD WORKING PAPERS ON INTERNATIONAL INVESTMENT}

are published on

www.oecd.org/daf/inv/investment-policy/working-papers.htm

This document and any map included herein are without prejudice to the status of or sovereignty over any territory, to the delimitation of international frontiers and boundaries and to the name of any territory, city or area.

\section{(c) OECD 2020}

You can copy, download or print OECD content for your own use, and you can include excerpts from OECD publications, databases and multimedia products in your own documents, presentations, blogs, websites and teaching materials, provided that suitable acknowledgment of OECD as source and copyright owner is given. All requests for commercial use and translation rights should be submitted to rights@oecd.org. 


\title{
Drivers of divestment decisions of multinational enterprises - A cross-country firm-level perspective
}

\author{
by
}

Maria Borga, Perla Ibarlucea-Flores and Monika Sztajerowska*

\begin{abstract}
Divestment by multinational enterprises is an important yet understudied phenomenon. The few available estimates indicate that about a fifth of all foreign affiliates are divested every five years. This paper presents the findings from a novel cross-country firm-level dataset with financial and ownership information for over 62000 foreignowned affiliates from a selection of 41 OECD and G20 countries and their economic groups from 164 home countries for the period 2007-2014. The data allow an assessment of the relative importance of different determinants of divestment in a cross-country setting, including host country policies and bilateral factors, including trade, investment and tax agreements. The findings confirm that parents divested about one of every five foreign-owned affiliates between 2007-2014 and show that a number of host country policy and economic factors, including labour costs and international trade agreements, influence the divestment decision, on top of the firm considerations considered in previous studies.
\end{abstract}

Authorised for release by Greg Medcraft, Director, OECD Directorate for Financial and Enterprise Affairs

Keywords: Multinational Firms, Divestment, International Investment, Preferential Trade Agreements, Bilateral Investment Treaties, Double Taxation Agreements

JEL Classification: F13, F14, F15, F23, F53

* Maria Borga, Perla Ibarlucea-Flores and Monika Sztajerowska work at the Investment Division of the OECD Department for Financial and Enterprise Affairs. The views in this article are those of the authors and do not purport to represent those of the OECD or its member countries. 


\section{Table of contents}

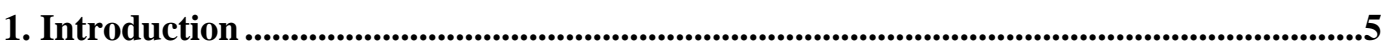

2. Literature review ….........................................................................................................

3. Descriptive evidence: Divestment patterns ............................................................................13

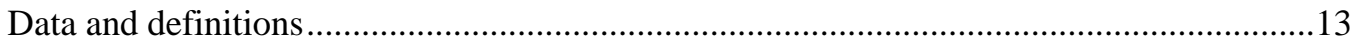

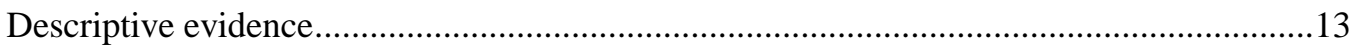

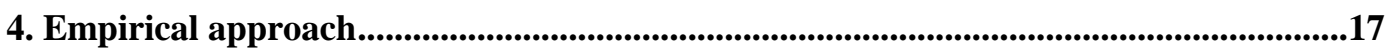

5. Estimation results ..............................................................................................................................22

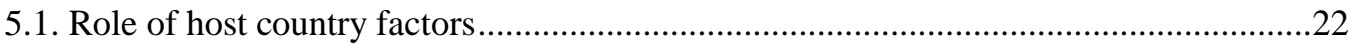

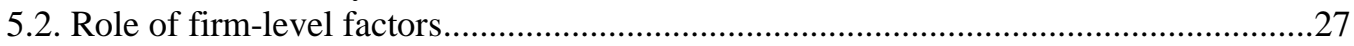

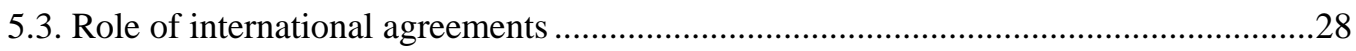

6. Robustness checks and heterogeneous effects of international agreements ....................30

7. Conclusions, further research and policy implications..........................................................34

Bibliography ...........................................................................................................................36

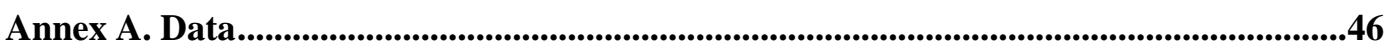

Annex B. Effect of foreign divestments on firm performance................................................50

Annex C. OECD Working Papers on International Investment............................................54

Tables

Table 1. Overview of host and home country-level factors that influence firm investment

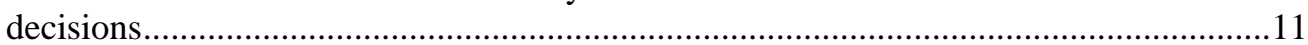

Table 2. Overview of factors that influence firm divestment decisions .................................12

Table 3. List of the variables used in the analysis .............................................................19

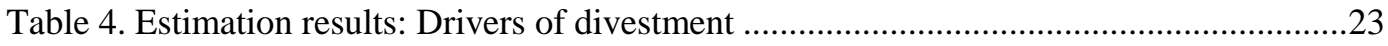

Table 5. Effect of international integration agreements: Robustness checks with alternative

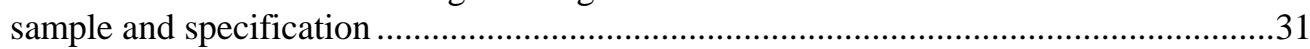

Table 6. Effect of international integration agreements: Heterogeneous effects ..................33

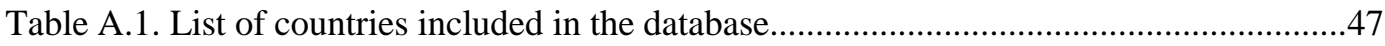

Table A.2. Summary statistics.........................................................................................49

Table B.1. Estimation results: Foreign divestments and acquisitions and performance of

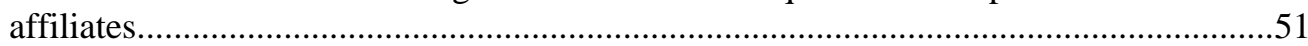

Table B.2. Estimation results: Foreign divestments and performance of affiliates firmsHeterogeneous effects according to the affiliate firm size …......................................52

Table B.3. Estimation results: Foreign divestments and performance of affiliates FirmsHeterogeneous effects according to the type of parent firm ............................................53

\section{Figures}

Figure 1. Number of divestments and share of divested firms in all foreign-owned firms, 2008-2014.

Figure 2. Foreign divestments rate by the sector of the affiliate firm, in \%, 2008-2014..........15

Figure 3. Number and value of foreign divestments and acquisitions, 2008-2014..................16

Figure A.1. Number of firms in the sample, by country, 2008-2014 .....................................48 


\section{Introduction}

Multinational enterprises (MNEs) are the dominant actors in the global market place, accounting for a majority share of world trade, fixed assets and innovation. According to OECD (2018a), the ratio of global inward foreign direct investment (FDI) stock to world GDP increased from $24 \%$ in 2005 to $41 \%$ in 2017. Multinational affiliate sales as a share of world GDP have also more than doubled in the past two decades, increasing from close to $25 \%$ in 1990 to $50 \%$ in 2017; and MNEs employ 82 million people, and are responsible for most of the world R\&D spending (UNCTAD, 2017). As such, MNE location decisions can impact global trade, investment and knowledge-creation and dissemination patterns, and can be of interest to the host economies in which they establish or maintain their operations.

This trend is reflected in the growing body of literature on the drivers and impacts of FDI in general, and MNE investment decisions (i.e. build, buy, expand) in particular. Meanwhile, much less attention has been paid to MNE divestment decisions (i.e. sell and exit), which means that MNE divestment decisions remain understudied and poorly understood.

In general terms, corporate divestment is an adjustment in the firm ownership and business portfolio structure, involving a partial or full disposal of an asset or a business unit. ${ }^{1}$ This paper focuses on foreign divestment to better understand the forces shaping FDI and to help to develop empirical foundations for a better conception of investment retention policies. Specifically, this paper defines divestment as a change in an affiliate's ownership structure that involves a transfer of majority-control over a firm from a foreign to a domestic owner, as per Javorcik and Poelhekke (2017). The focus is, therefore, on sales of affiliates; MNE business closures are not included for data and conceptual reasons. ${ }^{2}$ This definition is particularly pertinent to the study of FDI as it involves the loss of a foreign investor in the affiliate, which may negatively affect the firm's performance and the host economy's long-term growth prospects based on the FDI literature (e.g. Barba Navaretti and Venables, 2004).

Why should MNE divestments merit more attention from researchers and policy makers? First, divestment is a frequent corporate occurrence. For example, a study on the behaviour of US manufacturing MNEs, finds that $22 \%$ of their larger foreign affiliates (with sales or assets greater than USD 30 million) were divested between 1989 and 2004 (Berry, 2013).

\footnotetext{
${ }^{1}$ Corporate divestment can take numerous forms, e.g. sale, spin-off, equity carve-out, and leveraged buyout or disinvestment (i.e. a gradual reduction in investment funds or drawing profits away from the operation and reinvesting them elsewhere). See e.g. Buckley (1991).

${ }^{2}$ Business closures cannot be consistently identified in the ORBIS dataset. Even when firms that are identified as closed down, the information on the date of closure of an affiliate is not readily available in the database. In addition, the rich literature on foreign ownership and plant survival indicates business closures may be driven by factors different from those driving sales of affiliates (see e.g. Görg and Strobl, 2003; Bernard and Sjöholm, 2003; Girma and Görg; 2004; Van Beveren, 2007, Bernard and Jensen, 2007; Alvarez and Görg, 2009). While the existing evidence is sparse, closures appear to be relatively uncommon in MNE supply chains (Norbäck et al., 2015).
} 
Another study finds that $21.4 \%$ of the foreign affiliates of Swedish MNEs were divested at least once between 1998 and 2003 (Norbäck et al., 2015). ${ }^{3}$

Second, many public policies specifically aim to attract FDI and to encourage MNEs to locate in the local economy. For example, virtually every country has a national agency charged with the task of attracting FDI (OECD, 2018b; Harding and Javorcik, 2011 and 2012); international investment agreements grant foreign investors additional protections (e.g. Pohl, 2018; Sauvant and Sachs, 2009). OECD (2015a) includes a whole list of policies for promoting and facilitating investment, including some that specifically target foreign firms. Given this policy orientation, an understanding of drivers of MNE divestments can help policy makers shape policies both able to attract and retain FDI.

Last but not least, albeit the literature on this aspect is also sparse, existing studies suggest that divestment can have significant negative effects on the subsequent performance of the affected affiliates and it may potentially affect economic performance of the host and home economies in which they are located, including through dynamic long-term effects. ${ }^{4}$

Meanwhile, little is known about the determinants of MNE divestment decisions. Thus far, evidence has been largely confined to business case studies and analysis of various firmlevel factors only (see next section), including strategic and opportunistic reasons. For example, in 2017, General Electric announced a sale of more than USD 20 billion of its non-industrial segments as part of an effort to focus on its core business, reduce debt and generate cash (CNN, 2017 and 2018). Daimler and Nestlé mentioned similar motivations (Financial Times, 2018; Reuters, 2013). Businesses also routinely divest assets after mergers or acquisitions (M\&A) to satisfy requirements of competition authorities (e.g. Carlsberg in Sweden or RBS in the United Kingdom) or achieve greater group-wide efficiency (Capron et al., 2001). Firms may also divest due to technological change ${ }^{5}$ for political, ethical or socio-economic grounds (e.g. Soule et al., 2014 and OECD, 2015b); or in the face of a financial crisis or a major political development, such as Brexit. ${ }^{6}$

\footnotetext{
${ }^{3}$ A global survey conducted by Ernst \& Young (2019a) also finds that $84 \%$ of MNEs surveyed are planning to divest some of their operations within the next two years.

${ }^{4}$ From a conceptual perspective, if there existed no advantage of being owned by a foreign parent (e.g. in terms of productivity, access to knowledge, resources or markets), then a sale from a foreign to a domestic owner should have no significant impact on the performance of the firm postdivestment, beyond a potential disruption associated with a change in ownership. If, in turn, there are certain advantages associated with being owned by a foreign parent - as documented in the wide theoretical and empirical literature on FDI - then a foreign divestment would have a negative effect on firm performance. In addition, there could be possible spillover effects on other local firms in the economy. For a discussion of the theoretical and empirical FDI literature on the performance premium of MNEs, see Barba Navaretti and Venables (2004), and for a meta-analysis on FDI spillovers, see Görg and Strobl (2001) and Havránek and Iršová (2010, 2013). In addition, several studies specifically find a positive effect of foreign purchases on subsequent affiliate firm (or plant) performance (Arnold and Javorcik, 2009; Criscuolo and Martin, 2009; Guadalupe et al., 2012) while Javorcik and Poelhekke (2017) find a negative effect of foreign divestment on subsequent firm (or plant) performance.

${ }^{5}$ The examples of Kodak and Nokia, who were both pioneers in their respective industries, are among the more well-known (Reuters, 2013; Nokia, 2019).

6 Following the crisis of 2007-2008, several major global banks (e.g. RBS, Citibank) have undertaken significant restructuring (see e.g. Financial Times, 2017; Bloomberg, 2016), and, more
} 
The next section shows that virtually no cross-country economic studies examine the relative contribution of various firm-level and country-level factors to MNE divestment decisions. This means that little is known about the role of different policies in influencing the probability of divestment by MNEs. Today, a number of countries are implementing, or contemplating, policy changes that may potentially limit the scope for cross-border business activity, including terminations or renegotiations of existing international trade and investment agreements (OECD-UNCTAD, 2018). Further analysis of the impact of such agreements on firm divestment could help policymakers and the public assess the full scope of possible effects of the existence of such treaties, and the planned policy changes.

This paper fills in the current knowledge gap by studying drivers of MNE divestment decisions and considering firm-level and country-level factors, using a new large crosscountry dataset with detailed firm-level financial and ownership information for 41 selected OECD and G20 economies for the period between 2007 and 2014. ${ }^{7}$ It sheds new light on the role of host country as well as bilateral policies, in particular international investment agreements (IIAs), regional trade agreements (RTAs) and double-taxation treaties (DTTs), in influencing firm divestment decisions. The rest of the paper is structured as follows: section 2 provides a literature review and further explains the contribution of this study; section 3 presents the data and descriptive evidence on the importance of, and trends in, divestment. Section 4 presents the empirical approach; section 5 presents the estimation results; and section 6 presents robustness checks and exploration of heterogonous effects of international agreements. Section 7 concludes, outlining the scope of future research and possible policy implications.

recently, a number of companies announced their divestment intentions in the face of Brexit (e.g. Ernst \& Young, 2019b).

${ }^{7}$ The paper focuses on selected OECD and G20 economies due to data availability in the ORBIS database, see Annex A and OECD (forthcoming). 


\section{Literature review}

Rich theoretical and empirical literature on the determinants of FDI is available. ${ }^{8}$ Table 1 summarises the various policy and economic factors considered in the empirical studies. In contrast, the economic literature on drivers of firm divestment decisions is much less developed. For example, no comprehensive theoretical framework exists that could guide the analysis of firms' divestment decisions and explain how they differ from investment decisions. ${ }^{9}$ In addition, the current empirical literature on divestment is largely limited to management studies, focusing primarily on firm-level characteristics as factors explaining divestment probability (Table 2).

Panel A in Table 2 summarises the different firm-level factors considered in these studies. For example, the size of the affiliate or the parent has been predicted, and found empirically, to be positively associated with MNEs' divestment probability. The weak performance of the affiliate firm or business unit has also been confirmed to be a relevant factor explaining firm divestments, albeit predictions differ on the direction of the relationship. ${ }^{10}$ Many studies have also found that poor financial performance of the parent, such as high debt levels or low liquidity ratios, is an important predictor of firm divestments as firms sell parts of their business to meet short-term liquidity constraints. The degree of diversification of the parent firm's economic group as well as the size, geographical scope and internationalisation of its network of affiliates were also found to matter for MNE divestment decisions. ${ }^{11}$ Finally,

\footnotetext{
${ }^{8}$ For theoretical literature, see e.g. Rugman (1980), Helpman and Krugman (1984), Brainard (1997), Dunning (2000), Markusen (2002), Carr et al. (2001), Helpman et al. (2004), Helpman (2006), Caves (2007), Yeaple (2003) and Antràs and Yeaple (2014); or Chapter 1 in Barba Navaretti and Venables (2004) for their overview.

${ }^{9}$ Business literature provides some insights on firm motivations for divestments, including how they differ from investment decisions (e.g. Boddewyn, 1983b; Benito, 1997b) For example, Boddewyn's (1983b) applies Dunning's eclectic theory of investment to foreign divestment decisions highlights several considerations that differentiate a firm's decision to divest from the decision to invest (e.g. the role of affiliate-specific assets that can serve as barriers to exit in case of divestment; the decision to divest taking place in known locations; the role of a potential buyer (i.e. the need to make the asset attractive in order to be able to sell it) and the divisibility and saleability of assets. Harrigan (1981) also stresses the role of firm-specific assets.

${ }^{10}$ Some studies suggest that poorer performing affiliates would be shed as the MNE's capital can be usefully deployed elsewhere (see e.g. Brauer, 2006). Indeed, Berry (2010) measuring affiliate performance as return on assets and return on sales; and Berry (2013), measuring it as subsidiary profits minus taxes and unusual items scaled by assets, find a negative relationship between affiliate performance and divestment probability. Other studies suggest that increased profitability may make a business unit more independent, which may be associated with divestment (e.g. Fluck and Lynch, 1991).
}

${ }^{11}$ For example, Berry (2010 and 2013) used 4-digit SIC product categories to construct a firmspecific diversification measure and finds it to be positively related to divestment probability. In a widely cited paper, Kogut and Kulatilaka (1994) also explain that the network of affiliates gives a parent firm an "operational flexibility" that allows it to better respond to external shocks. This may mean that firms with a wider network, depending on shocks in different locations, can expand production outside of the host economy without the need to divest. Yet, empirical results remain mixed. For example, Berry (2010) considers the total number of foreign countries in which a firm 
the type of relationship between the affiliate and its parent and other affiliates in the economic group (e.g. sectoral relationship or presence of other affiliates of the same parent in the country) have also been analysed in the literature and found to influence divestment probability. ${ }^{12}$ In addition, as shown in Panel B in Table 2, certain industries may be more exposed than others to the risk of firm divestment, due to technological, regulatory, competition or other reasons, and are usually controlled for by variables capturing relevant industry-level characteristics (e.g. the degree of exposure to international competition, see Berry, 2013) or fixed-effects.

Meanwhile, the role of host and home country factors - including policies - remains largely under-studied, and is yet to attract the attention of mainstream economics. As can be seen in Panel $\mathrm{C}$ of Table 2, many of the factors considered relevant for firm investment decisions are missing from the analysis of divestment. Only a few studies - notably Berry (2010, 2013), Norbäck et al. (2015), and Javorcik and Poelhekke (2017) - have explored the role of such factors but have done so for only a single home or host country. This may be due to the fact that most of the earlier literature stems from business studies, concerned primarily with the role of firm factors, as well as related to the limited access to firm-level data for several host and home economies that could allow such an analysis.

As such, there is a large scope for better understanding if the same factors found to be important for investment attraction also matter (or not) for investment retention. Notably, considering that, unlike in the case of an initial investment decision, firms divest from known locations (i.e. locations in which they have operated in for some time), do certain factors become more or less important in these circumstances? For example, while tax policy has been found to be a consistently significant predictor of MNE investment decisions (e.g. see Mooij and Ederveen, 2003 for a meta-study), does it play the same role in MNE divestments? Similarly, do low labour costs, high quality of education or infrastructure, which are frequently stressed as important elements influencing MNE investment choices (see Table 1), also matter for MNE retention? More generally, further guidance on the relative role of different economic and policy factors in explaining firm divestment decisions could help elucidate the differences between successful investment attraction and retention.

Finally, a related stream of research is the literature on the impact of international investment, trade, and tax agreements on FDI and firm investment decisions. Apart from Blake and Moschieri (2017), there are no studies analysing the effect of international trade, investment and tax agreements on MNE divestment decisions. ${ }^{13}$ Meanwhile, there is a wide and growing literature on the impact of such treaties on trade, investment and cross-

has operations, and finds a positive relationship; while Norbäck et al. (2015) includes a measure of internationalisation (share of parent firm's foreign sales in total sales) and find a negative relationship to divestment.

12 Berry (2013) considers if the affiliate operates in the same 3-digit SIC code line as a foreign parent and finds that those do not have a higher divestment probability. Both Berry (2013) and Norbäck et al. (2015) control for the presence of other affiliates of the MNE in the same host country and find that it increases divestment probability.

13 Blake and Moschieri (2017) consider specifically the impact of investor-state disputes under investment treaties on firm divestment probability, finding a positive relationship between a dispute experienced by a host country and the likelihood of firm divestment in that country, conditional on other factors. 
border business decisions. ${ }^{14}$ In addition, given large differences in the design and depth of such agreements, increasingly the research focused on possible heterogeneous effects of treaties, depending on their content. ${ }^{15}$ There is, hence, a scope for understanding better the role of such agreements, and their design, in influencing firm divestment choices.

This study expands on the earlier literature to consider the relative role of the various firm as well as host and home country-level factors. In particular, besides firm characteristics explored in the divestment business studies, it includes a wide set of economic and policy variables found to be relevant to MNE location choices in the economic FDI literature. These include the size of the GDP, per capita income, exchange rate, inflation, unit labour costs, tax policy, trade policy and openness, and policy stability, among others. International trade, investment, and double taxation treaties are also included in the analysis. The study takes a cross-country perspective, studying the divestment decisions of firms operating in 41 host economies and from 164 home economies. Section 3 presents descriptive evidence on patterns of divestment, and Section 4 introduces the empirical approach that permits evaluation of the relative importance of these various determinants of firm divestment decisions identified in the literature, before results are presented.

14 The literature on the impact of PTAs and BITs on international investment yields conflicting findings. For example, some studies find positive effects of PTAs on investment (Baltagi et al., 2007b) and others insignificant or negative effects (Stein and Daude, 2007). The findings on the impact of BITs on FDI are similarly divided; for example, Egger and Merlo (2012) and Egger and Pfaffermayr (2004) find positive effects while Tobin and Rose-Ackerman (2005) and HallwardDriemeier (2003) none or negative effects (see Bellak, 2015 for a meta-analysis). In the case of DTTs, Blonigen and Davies (2004a, 2004b) and Di Giovanni (2005) find insignificant effects of such treaties on FDI stock and cross-border M\&A; Egger et al. (2009) find negative effects on outward FDI stock; while Blonigen et al. (2014) find significant positive effects on the probability of firms to establish in the economy.

${ }^{15}$ See Baier and Bergstrand (2007), Dür et al. (2014), Kohl (2014), Baier et al. (2014), Orefice and Rocha (2014), Kohl et al. (2016) for examples of studies on the importance of content of trade agreements; Berger et al. (2013) and Alschner and Skougarevskiy (2016) for studies on investment treaties and Blonigen et al. (2014) on double-taxation treaties. 
Table 1. Overview of host and home country-level factors that influence firm investment decisions

\begin{tabular}{|c|c|c|c|}
\hline Policies & Specific elements & Relationship & Relevant Studies \\
\hline $\begin{array}{l}\text { Market size and per } \\
\text { capita income }\end{array}$ & GDP level and per capita income & + & $\begin{array}{l}\text { Daude and Stein (2007), Di } \\
\text { Giovanni (2005), Bergstrand } \\
\text { and Egger (2007) }\end{array}$ \\
\hline Exchange rate & Exchange rate level or volatility & - & $\begin{array}{l}\text { Bénassy-Quéré et al. } \\
\text { (2001), Brzozowski (2006) }\end{array}$ \\
\hline Labour costs & Wages or Labour Units Costs & - & $\begin{array}{l}\text { Biswas (2002), Alam and } \\
\text { Shah (2013) }\end{array}$ \\
\hline Distance & $\begin{array}{l}\text { Geographic distance, border } \\
\text { adjacency, common language, } \\
\text { colonial ties }\end{array}$ & - & $\begin{array}{l}\text { Wheeler and Mody (1992) } \\
\text { Wei (2000), Di Giovanni } \\
\text { (2005), Alfaro et al. (2007), } \\
\text { Daude and Stein (2007), } \\
\text { Head and Ries (2008) }\end{array}$ \\
\hline Inflation & Inflation level or volatility & - & $\begin{array}{l}\text { Alfaro et al. (2007), Asiedu } \\
(2002)\end{array}$ \\
\hline $\begin{array}{l}\text { Agglomeration } \\
\text { effects }\end{array}$ & Presence of other foreign-owned firms & + & $\begin{array}{l}\text { Crozet et al. (2004), Disdier } \\
\text { and Mayer (2004) }\end{array}$ \\
\hline Taxation & Corporate tax levels, labour tax levels & - & $\begin{array}{l}\text { Arulampalam et al (2017), } \\
\text { Egger and Radulescu } \\
\text { (2011), Bellak et al. } \\
\text { (2009), Bellak and } \\
\text { Leibrecht (2009), De } \\
\text { Mooij and Ederveen } \\
\text { (2003), Alfaro et al. } \\
\text { (2007), Devereux and } \\
\text { Freeman (1995) }\end{array}$ \\
\hline Trade policy & Average tariffs, anti-dumping duties & $-/+$ & $\begin{array}{l}\text { Grubert and Mutti (1991), } \\
\text { Kogut and Chang (1996), } \\
\text { Blonigen (2002), Di } \\
\text { Giovanni (2005), Daude and } \\
\text { Stein (2007) }\end{array}$ \\
\hline $\begin{array}{l}\text { Quality of } \\
\text { institutions }\end{array}$ & $\begin{array}{l}\text { Quality of domestic institutions, } \\
\text { regulatory quality, the rule of law and } \\
\text { judicial system, control of corruption, } \\
\text { protection of intellectual property } \\
\text { rights }\end{array}$ & $+/-$ & $\begin{array}{l}\text { Bénassy-Quéré et al. (2007), } \\
\text { Daude and Stein (2007), } \\
\text { Alfaro et al. (2007), Wei } \\
\text { (2000, 1997), Javorcik and } \\
\text { Spatareanu (2005), Javorcik, } \\
\text { (2004b ), Javorcik and Wei } \\
\text { (2009), Biswas (2002) }\end{array}$ \\
\hline $\begin{array}{l}\text { Education and } \\
\text { human capital }\end{array}$ & $\begin{array}{l}\text { Years of total schooling, percentage } \\
\text { of adults who are literate }\end{array}$ & $+/-$ & $\begin{array}{l}\text { Alfaro et al. (2007), } \\
\text { Noorbakhsh et al. (2001) }\end{array}$ \\
\hline Infrastructure & $\begin{array}{l}\text { Quality of transport, communications, } \\
\text { energy } \\
\text { infrastructure }\end{array}$ & + & $\begin{array}{l}\text { Kinda (2010), Bellak et al. } \\
(2009) \text {, Asiedu (2002), } \\
\text { Biswas (2002), Wheeler } \\
\text { and Mody (1992) }\end{array}$ \\
\hline Investment policy & $\begin{array}{l}\text { Lack of FDI restrictions; the ease of } \\
\text { doing business; sectoral targeting or } \\
\text { quality of investment promotion } \\
\text { agencies }\end{array}$ & + & $\begin{array}{l}\text { Mistura and Roulet (2019), } \\
\text { Corcoran and Gillanders } \\
\text { (2015), Harding and } \\
\text { Javorcik (2011, 2012), } \\
\text { Nicoletti et al. (2003) }\end{array}$ \\
\hline $\begin{array}{l}\text { International } \\
\text { investment, trade } \\
\text { and tax agreements }\end{array}$ & $\begin{array}{l}\text { Bilateral investment agreements, } \\
\text { preferential trade agreements, double } \\
\text { taxation treaties }\end{array}$ & $+/-$ & $\begin{array}{l}\text { Blyde et al. (2015), } \\
\text { Blonigen et al. (2014), } \\
\text { Egger and Merlo (2012), } \\
\text { Egger et al. (2009); Baltagi } \\
\text { et al.(2008); Egger and } \\
\text { Pfaffermayr (2004), } \\
\text { Blonigen and Davies } \\
\text { (2004, 2005) }\end{array}$ \\
\hline
\end{tabular}


Table 2. Overview of factors that influence firm divestment decisions

\begin{tabular}{|c|c|c|}
\hline Factors considered & Relationship & Relevant Studies \\
\hline \multicolumn{3}{|c|}{ Panel A. Firm-level or business unit-level factors } \\
\hline Size (of the affiliate or the parent) & + & $\begin{array}{l}\text { Norbäck et al. (2015), Berry (2010), Sembenelli and } \\
\text { Vannoni (2003); Shimizu and Hitt (2005), Duhaime and } \\
\text { Grant (1984) Bergh (1997), Hamilton and Chow (1993), }\end{array}$ \\
\hline Parent's performance & - & $\begin{array}{l}\text { Berry (2010), Dranikoff et al. (2002), Markides (1992), } \\
\text { Pashley and Philippatos (1990), Montgomery and } \\
\text { Thomas (1988), Duhaime and Grant (1984), Harrigan } \\
(1981,1982)\end{array}$ \\
\hline Affiliate's performance & $-/+$ & $\begin{array}{l}\text { Berry (2013), Hitt et al. (1996), Chang (1996), } \\
\text { Hoskisson and Johnson (1992), Hamilton and Chow } \\
\text { (1993), Markides (1992), Montgomery and Thomas } \\
\text { (1988), Ravenscraft and Scherer (1987), Duhaime and } \\
\text { Grant (1984), Harrigan (1981) }\end{array}$ \\
\hline Business relatedness & + & $\begin{array}{l}\text { Berry (2010, 2013), Capron et al. (2001), Zuckerman } \\
\text { (2000), Bergh (1995, 1997), Harrigan (1981, 1985), } \\
\text { Hoskisson et al., (1994) }\end{array}$ \\
\hline Business diversification & + & $\begin{array}{l}\text { Berry (2010, 2013), Chang and Singh (1999), Bergh } \\
\text { (1997), Chang (1996), Hoskisson and Hitt (1994), } \\
\text { Duhaime and Grant (1984) }\end{array}$ \\
\hline $\begin{array}{l}\text { Internationalisation / the } \\
\text { geographic scope of the } \\
\text { economic group }\end{array}$ & $+/-$ & Norbäck et al. (2015), Berry (2010, 2013) \\
\hline Existence of other affiliates & + & Norbäck et al. (2015), Berry $(2010,2013)$ \\
\hline Other divestments/acquisitions & $+/-$ & $\begin{array}{l}\text { Procher and Engel (2017), Norbäck et al. (2015), Berry } \\
(2010) \text {, Capron et al. (2001) }\end{array}$ \\
\hline Strong parent firm governance & + & $\begin{array}{l}\text { Chatterjee et al. (2003), Sanders (2001), Hoskisson et } \\
\text { al. (1994); Johnson et al. (1993) }\end{array}$ \\
\hline \multicolumn{3}{|c|}{ Panel B. Sector-level factors } \\
\hline Growth & $+/-$ & $\begin{array}{l}\text { Berry (2010), Sembenelli and Vannoni (2000), } \\
\text { Ilmakunnas and Topi (1999), Harrigan (1982) }\end{array}$ \\
\hline Concentration & $+/-$ & $\begin{array}{l}\text { Norbäck (2015), Tan and Yuan (2003), Chang and } \\
\text { Singh (1999), Ilmakunnas and Topi (1999) }\end{array}$ \\
\hline Technological change & + & $\begin{array}{l}\text { Harrigan (1982), Jovanovic and MacDonald (1994), } \\
\text { Jensen (1993) }\end{array}$ \\
\hline $\begin{array}{l}\text { Changes to regulation and } \\
\text { institutional setting }\end{array}$ & + & $\begin{array}{l}\text { Norbäck et al. (2015), Chatterjee et al. (2003), Bergh } \\
\text { and Lawless (1998), Shleifer and Vishny (1991), } \\
\text { Hoskisson and Hitt (1990), Turk and Baysinger (1989) }\end{array}$ \\
\hline Level of internationalisation & $+/-$ & Berry (2013) \\
\hline Sunk costs & & $\begin{array}{l}\text { Harrigan (1982), Sembenelli and Vannoni (2003), } \\
\text { Norbäck et al. (2015) }\end{array}$ \\
\hline \multicolumn{3}{|c|}{ Panel C. Host country-level factors } \\
\hline GDP & - & $\begin{array}{l}\text { Norbäck et al. (2015), Blake and Moschieri (2017), } \\
\text { Berry (2010) }\end{array}$ \\
\hline Real exchange rate volatility & + & Berry (2010) \\
\hline Capital-to-labour ratio & - & Norbäck et al. (2015) \\
\hline Wages & + & Berry (2010) \\
\hline Trade openness & + & Norbäck et al. (2015) \\
\hline Skills & + & Norbäck et al. (2015) \\
\hline Policy stability & - & Blake and Moschieri (2017), Berry (2013) \\
\hline ISDS disputes against the host & + & Blake and Moschieri (2017) \\
\hline
\end{tabular}




\section{Descriptive evidence: Divestment patterns}

\section{Data and definitions}

The data used in this paper come from several different sources. First, the firm-level data is based on the information from Bureau van Dijk's ORBIS database. As explained in several recent studies of FDI and MNE activity, the ORBIS database offers one of the richest sources of firm-level data with ownership and financial information available for a number of countries over time (e.g. Fons-Rosen et al., 2013; Kalemli-Ozcan et al., 2015; Alfaro and Chen, 2018; Chen and Bao, 2018). In particular, for OECD countries, which are the focus of this paper, it offers good coverage of MNE activity and the official FDI statistics (e.g. see Kalemli-Ozcan et al., 2015 and Alfaro and Chen, 2018). As such, it offers an attractive tool to study the drivers of divestment decisions, as well as changes in firm ownership structure more generally, in ways that were previously possible for selected countries or groups of investors only (see Section 2).

After a thorough data-construction and cleaning exercise, a panel dataset has been created, containing financial and ownership information on over 62000 foreign-owned affiliates, located in 41 selected OECD and G20 countries and those firms' parents as well as their economic groups located in 164 different countries. ${ }^{16}$ As such, the dataset tracks those affiliates each year during the period 2007-2014 in order to identify when they were sold by their foreign parents, either to domestic or foreign owners. As explained at the outset. this paper focuses on foreign divestments and follows Javorcik and Poelhekke (2017) to define such divestments as a change in the affiliate's ownership structure that involves a transfer of majority-control over a firm from a foreign to a domestic owner. Finally, this approach takes into account solely changes in the company's global ultimate owner, i.e. the individual or entity at the top of the corporate ownership structure, in order to capture shifts that affect the beneficial ownership of an affiliate, and exclude other corporate restructuring.

All the definitions of the variables used as well as the associated sources are listed in Table 3. Most data for country-level variables come from the World Bank's World Development Indicators Database, World Economic Forum's Global Competitiveness Index, the WTO, CEPII as well as the relevant OECD databases (e.g. OECD Productivity Database and OECD Environmental Policy Stringency Index). The information on the coverage of international trade, investment and tax agreements comes from the OECD International Investment Agreements database, Baier et al. (2014), as well as the OECD and the Exchange of Tax Information Portal of the Global Forum on Transparency. All variables for the affiliate firms and economic groups of their parents are constructed using ORBIS. ${ }^{17}$

\section{Descriptive evidence}

Overall, using definitions and data described above, it is found that $22 \%$ of firms that were foreign-owned at the start of the sample period were divested at least once by their foreignowned parent (representing about 13000 divestments throughout the whole period). This

\footnotetext{
${ }^{16}$ See Annex A and (OECD, forthcoming) for more information.

${ }^{17}$ Financial information on the affiliate firms (parent firm's economic groups) comes from the unconsolidated (consolidated) accounts reported in ORBIS (see OECD, forthcoming)
} 
translates into an annual rate of about $4 \%$, which is commensurate with other studies. ${ }^{18}$ Using another metric, 34\% of all total assets of foreign-owned firms in 2007 have been divested by 2014, accounting for $17 \%$ of their sales and $23 \%$ of their employees.

Figure 1 shows the evolution of the number of divested firms observed in the sample as well as their share in all foreign-owned firms in different years. As can be seen, divestment rates vary over time, potentially responding to fluctuations in the business cycle and other time-varying factors. Divestment shares also differ by sector (Figure 2), being relatively higher in certain services sectors, also pointing to the importance of sector characteristics. These trends highlight the need to account for a series of macroeconomic, sectoral and other structural factors to establish the effect of various drivers on the probability of MNE divestment of an affiliate.

\section{Figure 1. Number of divestments and share of divested firms in all foreign-} owned firms, 2008-2014.

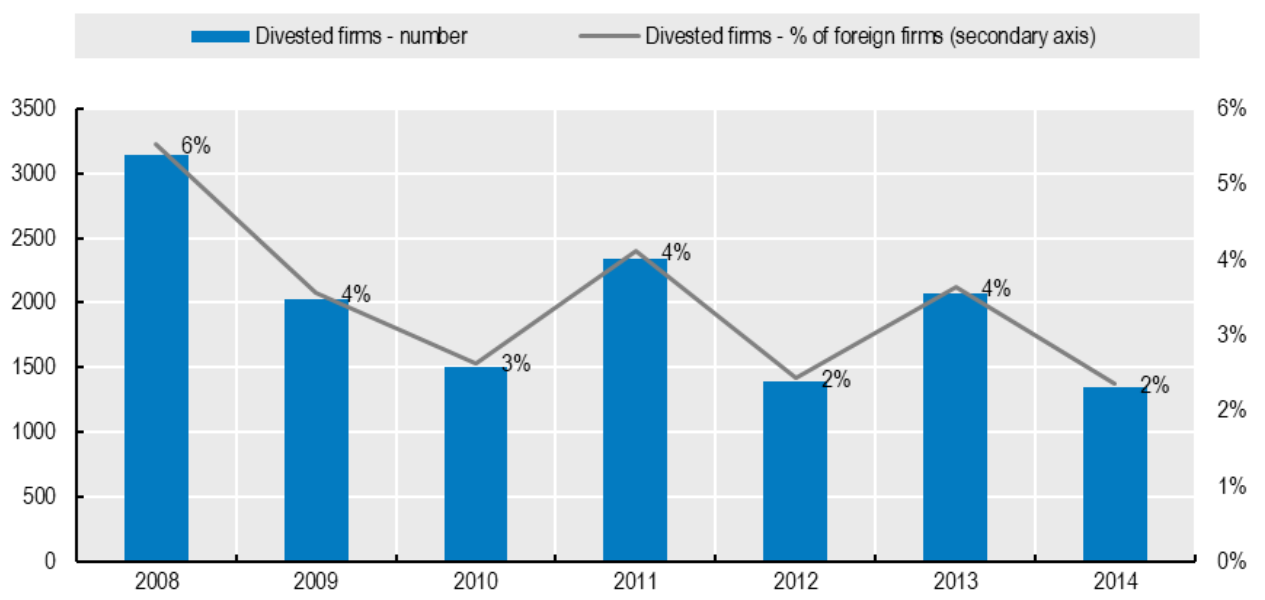

Note: A foreign divestment refers to a situation when a foreign global ultimate owner of an affiliate in year t1 ceases to have a majority control over that affiliate in year $t$ and a domestic owner commences to exert a majority control. Divestment share here refers to the number of divested firms to the total number of foreignowned firms that year.

Source: OECD calculations using ORBIS @ data.

Comparing the evolution of foreign divestments and acquisitions over time can provide additional insights. Figure 3 and 4 show the relative importance of foreign divestments to foreign acquisitions in the sample period. On net, foreign acquisitions outnumber foreign divestments in most years between 2007 and 2014. Yet, in some years, the number as well as the value of total assets of foreign divestments are as significant, or even outweigh foreign acquisitions. This suggests that divestment is not a trivial phenomenon and can potentially affect a sizable share of business activity. Combined with existing evidence on the possible negative effect on the sold-off affiliate's performance, it merits further attention and analysis of factors that may explain it. ${ }^{19}$

18 Despite differences in definitions and time periods in several earlier country studies, they generally find an annual divestment rate to be between 1.7 and 4\%. In addition to Berry (2013) and Norbäck et al. (2015), cited earlier, Belderbos et al. (2006) and Belderbos (2003) find annual divestment rates of Japanese MNEs in electronics manufacturing in ASEAN and Europe to be about 3\%. UNCTAD (2009) also reports that divestments "affect between one quarter and four fifths of all FDI projects".

${ }^{19}$ For example, Javorcik and Poelhekke (2017), using a detailed plant-level panel dataset from Indonesia, find that the sold-off plants experienced a subsequent $3.8 \%$ drop in productivity, a $28 \%$ drop in output, and 
The summary statistics for the variables included in the model outlined in the next section are included in Table A.2 in Annex A at the end of this paper.

Figure 2. Foreign divestments rate by the sector of the affiliate firm, in \%, 2008-2014.

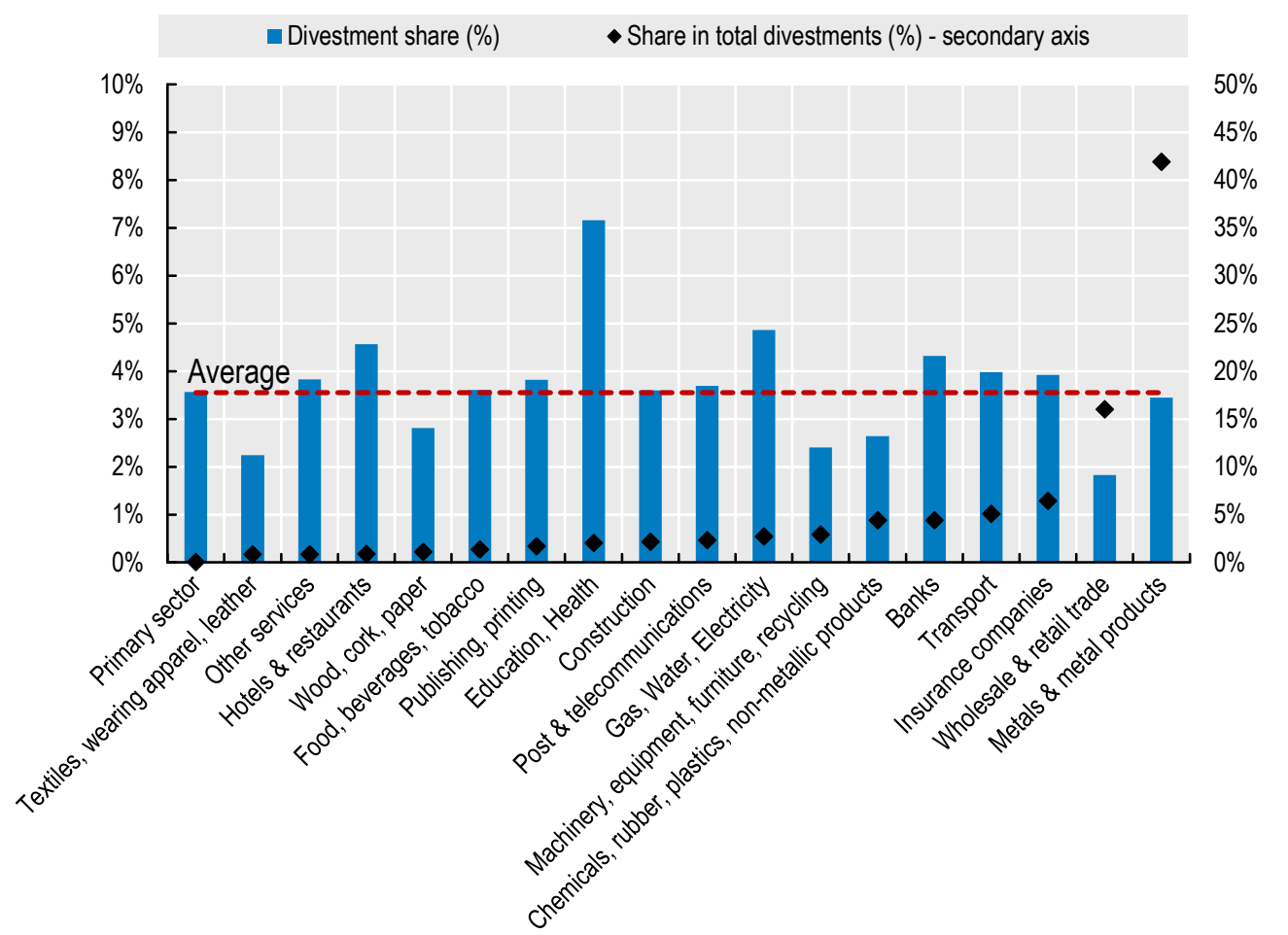

Note: A foreign divestment refers to a situation when a foreign-owned global ultimate owner of an affiliate in year $t-1$ ceases to have a majority control over that affiliate in year $t$ and a domestic-owned firm commences to exert a majority control. Divestment rate is defined as the share of divestments to the total number of foreignowned firms in a given sector. The broad sector classification shown here is provided by ORBIS; the empirical analysis presented later uses NAICS sector classification.

Source: OECD calculations using ORBIS $\odot$ data.

a $15.3 \%$ drop in blue-collar employment relative to the control group of similar firms that have not been divested. Analysis using the firm-level data employed in this paper also finds a negative relationship between foreign divestment and the performance of the divested affiliates relative to firms that stayed foreign-owned through the period (see Table B1 in Annex B). 
Figure 3. Number and value of foreign divestments and acquisitions, 2008-2014.

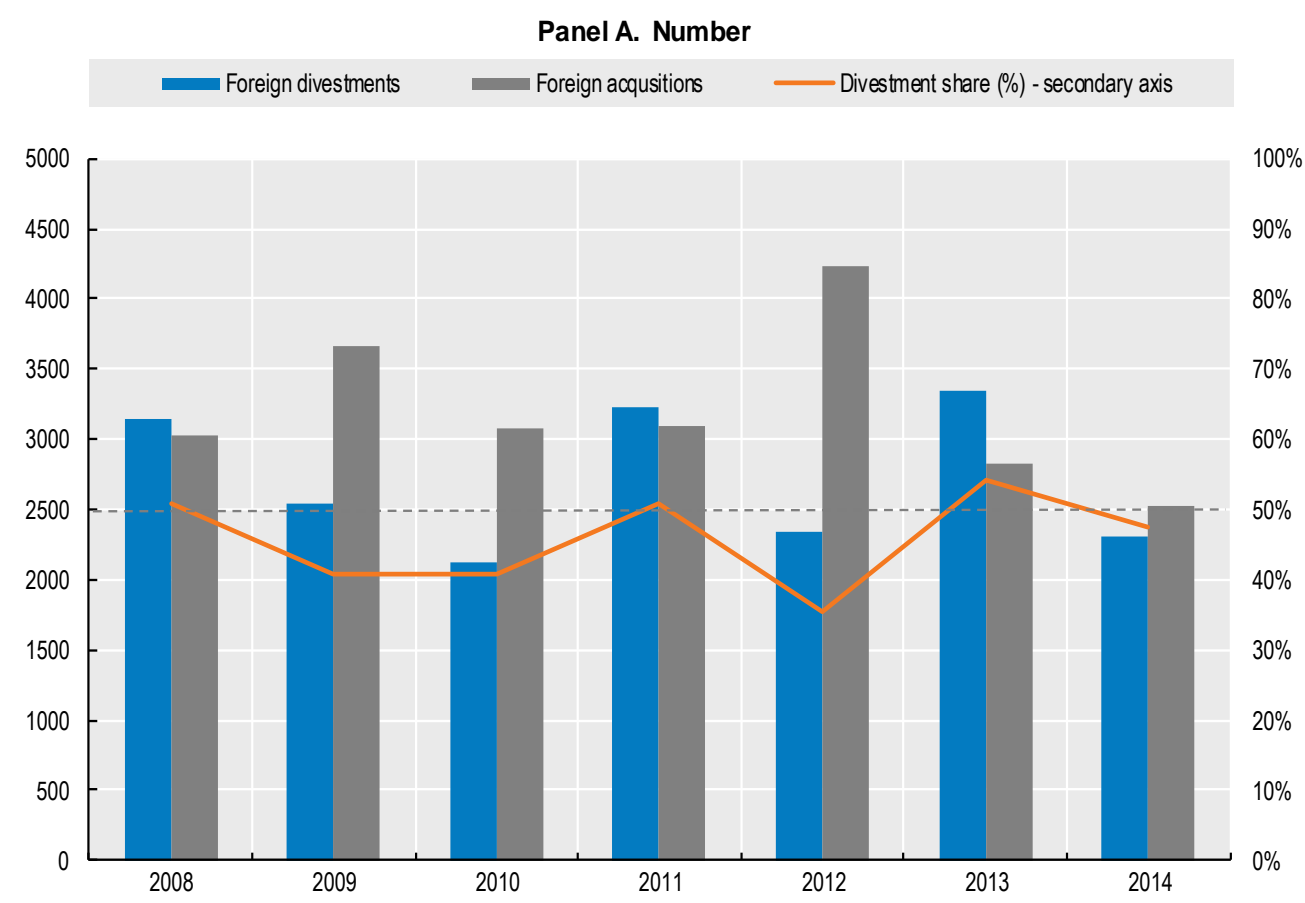

Panel B. Value of total assets (in billion EUR)

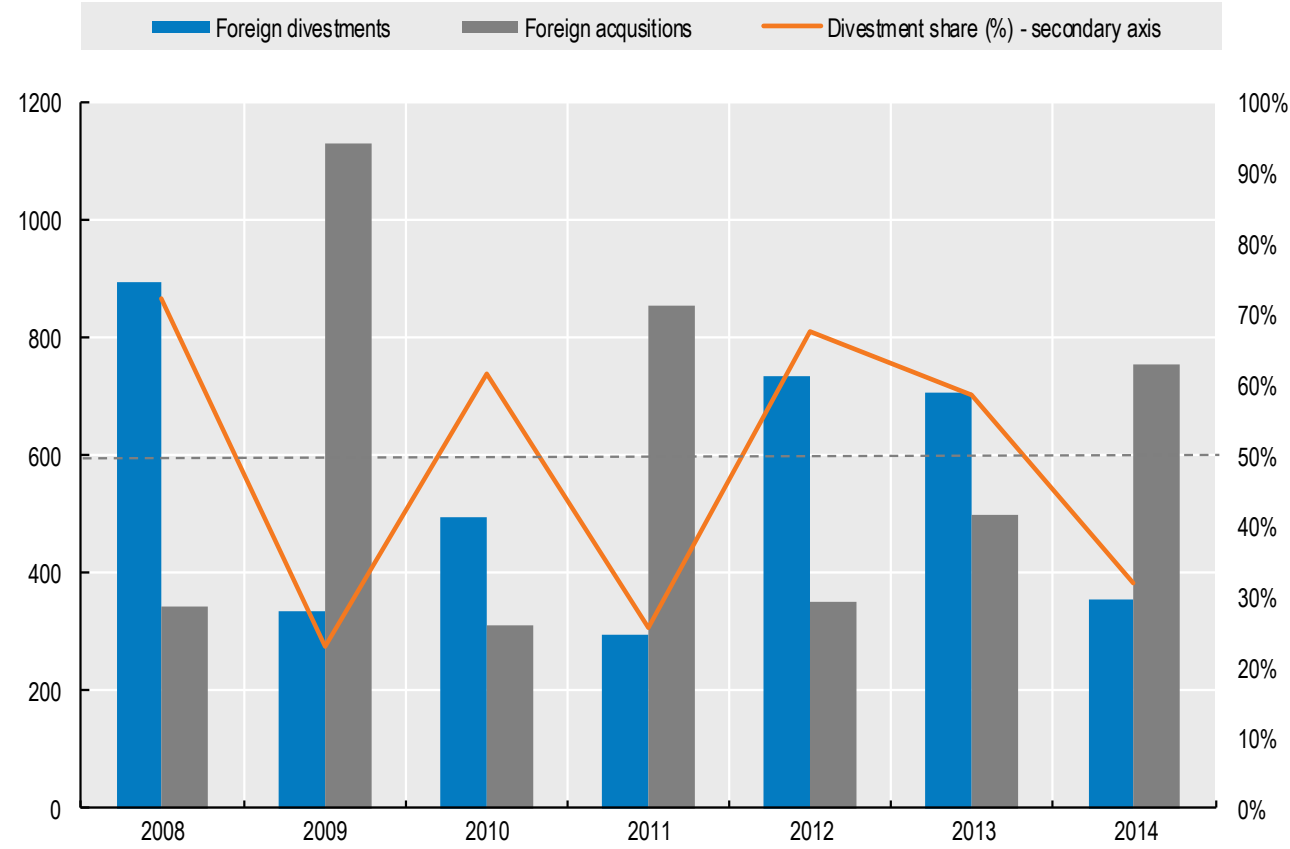

Note: A foreign divestment refers to a situation when a foreign-owned global ultimate owner of an affiliate in year $\mathrm{t}-1$ ceases to have a majority control over that affiliate in year $\mathrm{t}$ and a domestic-owned firm commences to exert a majority control. A foreign acquisition refers to a situation when a domestic-owned global ultimate owner of an affiliate in year t-1 ceases to have a majority control over that affiliate in year $\mathrm{t}$ and a foreignowned firm commences to exert majority control. Divestment share is the share of foreign divestments to the sum of all foreign divestments and acquisitions in a given year.

Source: OECD calculations using ORBIS $\odot$ data. 


\section{Empirical approach}

A linear probability model is used to identify the impact of various country- and firm-level factors on firms' divestment decisions. The reason is threefold. First, OLS estimation is simple and the respective estimates are easily and directly interpretable. As such, it has been applied, among other reasons, in several empirical studies focusing on the determinants of binary outcome variables (e.g., Bernard and Jensen, 2004). Second, in practice, the estimated effects generated by nonlinear models are likely to be very similar to their OLS counterparts (Angrist, 2001, 2006). ${ }^{20}$ Third, non-linear models may yield inconsistent estimates when a large number of fixed effects is included to account for several unobserved relevant factors and thus avoid omitted variable biases. ${ }^{21}$ The specific estimation equation is as follows:

$$
D_{f s c e h t}=\beta_{1} X_{c t-1}+\beta_{2} W_{c h(t-1)}+\beta_{3} Y_{f t-1}+\beta_{4} Z_{e t-1}+\gamma_{c s}+\delta_{h s t}+\varepsilon_{f s c e h t}
$$

where $D_{f \operatorname{csh}(e) t}$ is a binary variable that takes a value of 1 if an affiliate $f$ in a (4-digit NAICS classification) sector $s$ in a host country $c$ is divested (i.e. ceases to have majority control) by its foreign-owned parent belonging to an economic group $e$ in a home country $h$ in a given year $t$, and zero otherwise; $X_{c t-1}$ is a vector of relevant (time-variant) host country economic and policy characteristics, selected based on their use in the existing literature on the drivers of FDI and firm divestment decisions (listed in Panel A of Table 3 underneath). $W_{c h(t-1)}$ is a vector of relevant bilateral host-home country-pair characteristics, notably the existence of IIAs, RTAs, and DTTs between the countries of location of the affiliate and its parent firm (see Panel B in Table 3). $Y_{f t-1}$ is a vector of relevant (time-variant) affiliate firm-level characteristics listed in Panel C in Table 3; and $Z_{e t-1}$ is a vector of relevant (time-variant) economic group-level characteristics, listed in Panel D in the same table. The rest of the terms are relevant fixed effects, accounting for different sources of time-invariant and time-variant heterogeneity; $\gamma_{c s}$ - host countrysector fixed effects; $\delta_{h s t}$ - home country-sector-year fixed effects; and $\varepsilon$ is the error term. ${ }^{22}$

A number of (time-variant) controls at the affiliate- and the parent's economic group-level (i.e. $Y_{f t-1}$ and $Z_{e t-1}$, respectively), are constructed using the firm-level dataset described in the earlier section. The choice of the variables considered is guided by the earlier literature (see

\footnotetext{
${ }^{20}$ This is the case due to a general regression property according to which, regardless of the conditional mean function being estimated, OLS regression always provides the minimum mean square approximation to it (e.g. Goldberger, 1991). At the outset of the research, probit and logit models were estimated for the same set of specifications (without inclusion of the full set of relevant fixed effects) and the results were very close to the OLS-based ones.

21 This is the well-known "incidental parameter problem" first analysed by Neyman and Scott (1948) (see also Lancaster, 2000).

${ }^{22}$ Lags are used to alleviate potential simultaneity problems (e.g. if a large divestment is associated with a simultaneous drop in GDP or in other ways impacts some of the explanatory variables or may lead to change in the policy of a country) as well as to account for the possibility that the decision to divest may lag behind the initial factor prompting it (e.g. a firm observes reduced return on assets in year $t$ and incorporating this decision into its strategy decides to divest in $t+1$ ).
} 
Section 2). For example, building on earlier studies (e.g. Berry, 2010, 2013; Norbäck et al. 2015), the size of the affiliate (proxied by the size of its fixed assets), its financial performance (proxied by the return on assets, ROA) or financial health (proxied by its liquidity ratio) are examined to see if they influence the probability of the affiliate being divested by its foreign parent, ceteris paribus. Similarly, controls for the size, financial performance and health of the economic group of the foreign parent are included, building on earlier studies. The "opportunistic" versus "strategic" motivations of MNEs for divesting affiliates, i.e. those motivated by short-term liquidity constraints versus those linked to the desire to refocus on the firm's core business (e.g. Markides, 1992), are considered by including relevant controls for the sectoral and geographic nature of the parent's economic group and its ability to service debt. ${ }^{23}$ Finally, as also done elsewhere, several measures of interaction between the parent's economic group and the affiliate firm, such as whether they operate in the same 4-digit NAICS sectors, and if there are any other affiliates of the same parent operating in the host country of the affiliate (see Panel C and D in Table 3), are taken into account.

To control for host-country, home-country and host-home county pair characteristics, a mix of relevant time-variant country characteristics and appropriate fixed effects are included. For example, in the baseline regressions, to explore the role of different host-country and bilateral country-pair considerations, home-country-time fixed effects $\left(\delta_{h s t}\right)$ and a series of timevariant economic and policy host-country factors and time-variant and time-invariant bilateral characteristics, are included as has been done in the FDI literature (Panels A and B in Table 3). When the focus is on the role of international agreements, these host country characteristics are later absorbed by the relevant host-country-(sector)-time fixed effects $\left(\gamma_{C(s) t}\right)$ to control for sources of unobserved heterogeneity along this dimension.

In the second stage, additional robustness checks are performed to better corroborate the effects of bilateral host-home country factors, including RTAs, IIAs and DTTs, on foreign divestment probability. First, to test if the effect of treaties varies depending on the sample composition, the sample is increased to include all 146 countries for which firm-level ownership information over time is available in ORBIS. ${ }^{24}$ Second, to account for potential sources of unobserved heterogeneity and relax the timing assumptions regarding the impact of international agreements on divestment decisions, and thereby alleviate potential endogeneity concerns, the following alternative specification is used:

$$
\Delta D_{\text {fsceht }_{0}}=\beta_{1} I I A_{\text {cht }}+\beta_{2} R T A_{c h t_{0}}+\beta_{3} D T T_{c h t_{0}}+\gamma_{c s}+\delta_{h s}+\varepsilon_{f s c e h}
$$

where $\Delta D_{f_{\text {cshet }}}$ is a binary variable that takes a value of 1 if an affiliate $f$ in a (4-digit NAICS classification) sector $s$ in a host country $c$ that was foreign-owned in 2007 was divested (i.e. ceased to have majority control) by its foreign parent belonging to an

\footnotetext{
${ }^{23}$ While inherently difficult to capture, this paper builds on earlier studies described in Section 2 and considers the parent's ability to meet its debt obligations as proxied by the economic group's insolvency ratio (i.e. the ratio of shareholders' funds to total assets) and its current financial constraints as proxied by the liquidity ratio (i.e. ratio of current assets to current liabilities) to capture the parent's potential motivation to sell affiliates to gather funds. Strategic factors are based on earlier studies and are captured by metrics of sectoral spread (i.e. number of 4-digit NAICS sectors in which the economic group operates), geographic breadth (i.e. number of countries) as well as the level of internationalisation of the MNE global network of affiliates (i.e. the share of foreign affiliate to all affiliates in the group).

${ }^{24}$ This expansion means adopting an alternative specification because, among other reasons, the sample does not have data for all of the affiliate-level and group-level variables included above.
} 
economic group $e$ in a home country $h$ at some point between 2007 and 2014, and zero otherwise $\left(\Delta D_{f s c e h t_{0}}=D_{f s c e h(2008-2014)}-D_{f s c e h(2007)}\right)$ and where $D_{f s c e h t_{0}}$ is equal to 0 for all firms because all firms are foreign-owned in 2007; II $A_{c h t_{0}}$ is a binary variable that takes a value of 1 if there was an IIA in place between the host country of the affiliate $f$ and the home country of its economic group's parent $e$ at the beginning of the sample period and 0 otherwise; $R T A_{c h t_{0}}$ is a binary variable that takes a value of 1 if there was an RTA in place between the host country of the affiliate $f$ and the home country of its economic group's parent $e$ at the beginning of the sample period and 0 otherwise; $D T T_{\text {cht }}$ is a binary variable that takes a value of 1 if there was a DTT in place between the host country of the affiliate $f$ and the home country of its economic group's parent $e$ at the beginning of the sample period and 0 otherwise. The rest of the terms are relevant fixed effects, accounting for different sources of time-invariant and time-variant heterogeneity; $\gamma_{c s}$ - host country sector fixed effects and $\delta_{h s}$-home sector fixed effects; and $\varepsilon$ is the error term.

Finally, the existence of possible heterogeneous effects of agreements is explored, depending on their content. For this purpose, the classification of RTAs according to their depth developed by Baier et al. (2014) is used to provide nuance in place of the earlier employed RTA dummy. In particular, RTAs are divided into two groups: Shallow RTAs covering preferential trade agreements (PTAs) and free trade agreements and Deep RTAs, covering customs unions, customs markets and economic unions, and these two variables are used in place of the RTA dummy in both specifications outlined above.

In line with the literature, some of the different factors at the firm, country- and countrypair level explored in earlier studies are expected to be statistically significant determinants of MNE divestments. In the first instance, all of them are included in the benchmark specification to assess their relative importance. Then, progressively more stringent specifications are introduced that include fixed effects to control for some of these factors such as time-variant host-country and home-country and time-invariant host-home effects - to focus on time-variant bilateral country variables (i.e. international agreements), and explore the existence of possible heterogeneous effects. Table 3 provides the definitions of all variables used as well as the expected signs of the relationship.

Table 3. List of the variables used in the analysis

\begin{tabular}{|c|c|c|c|}
\hline Variable & & Definition & Source \\
\hline \multicolumn{4}{|c|}{ Panel A. Host Country Variables } \\
\hline $\log G D P t-1$ & - & Size of GDP (current LCU) & $\begin{array}{l}\text { World Bank's World } \\
\text { Development } \\
\text { Indicators }\end{array}$ \\
\hline $\log G D P p c t-1$ & + & GDP per capita income & $\begin{array}{l}\text { World Bank's World } \\
\text { Development } \\
\text { Indicators }\end{array}$ \\
\hline Log Real Exchange Rate $t-1$ & + & $\begin{array}{l}\text { Real effective exchange rate index }(2010 \\
=100)\end{array}$ & $\begin{array}{l}\text { World Bank's World } \\
\text { Development } \\
\text { Indicators }\end{array}$ \\
\hline $\begin{array}{l}\text { Log Real Exchange Rate } \\
\text { Variability } t-1\end{array}$ & + & $\begin{array}{l}\text { Standard deviation in real exchange rate } \\
\text { changes over the prior three-year period }\end{array}$ & $\begin{array}{l}\text { Authors' calculation } \\
\text { using the World } \\
\text { Bank's World } \\
\text { Development } \\
\text { Indicators }\end{array}$ \\
\hline Log Trade-to-GDP & + & (Exports+Imports)/GDP(\%) & WTO \\
\hline
\end{tabular}




\begin{tabular}{|c|c|c|c|}
\hline Log Unit Labour Costs (ULC) & + & $\begin{array}{l}\text { Labour compensation per unit of labour } \\
\text { input / Labour productivity, i.e. output per } \\
\text { hour worked (Index, } 2010=100 \text {, total } \\
\text { economy, annual) }\end{array}$ & $\begin{array}{l}\text { OECD Productivity } \\
\text { database }\end{array}$ \\
\hline Log Tax rate $t-1$ & + & Total tax rate (\% of commercial profits) & $\begin{array}{l}\text { World Bank's World } \\
\text { Development } \\
\text { Indicators }\end{array}$ \\
\hline $\begin{array}{l}\text { Log Applied Trade Tariff Rate } \\
t-1\end{array}$ & + & $\begin{array}{l}\text { Tariff rate, applied, simple mean, } \\
\text { manufactured products }(\%)\end{array}$ & $\begin{array}{l}\text { World Bank's World } \\
\text { Development } \\
\text { Indicators }\end{array}$ \\
\hline Log Time to Trade $t-1$ & + & $\begin{array}{l}\text { Average time to import and export } \\
\text { (days) }\end{array}$ & $\begin{array}{l}\text { World Bank's World } \\
\text { Development } \\
\text { Indicators }\end{array}$ \\
\hline $\begin{array}{l}\text { Log Quality of Overall } \\
\text { Infrastructure } t-1\end{array}$ & - & $\begin{array}{l}\text { Quality of overall infrastructure, 1-7 } \\
\text { (best) }\end{array}$ & $\begin{array}{l}\text { World Economic } \\
\text { Forum Global } \\
\text { Competitiveness Index }\end{array}$ \\
\hline Log Corruption (TI) $t-1$ & - & $\begin{array}{l}\text { Corruption Perception Index }(0=\text { highly } \\
\text { corrupt; } 100=\text { very clean.) }\end{array}$ & $\begin{array}{l}\text { Transparency } \\
\text { International }\end{array}$ \\
\hline Log Political Stability $t-1$ & - & $\begin{array}{l}\text { Political Stability (higher='better' } \\
\text { performance) }\end{array}$ & $\begin{array}{l}\text { World Banks's } \\
\text { Worldwide } \\
\text { Governance Indicators }\end{array}$ \\
\hline Log Education $t-1$ & - & $\begin{array}{l}\text { Labour force with advanced education (\% } \\
\text { of total working-age population with } \\
\text { advanced education) }\end{array}$ & $\begin{array}{l}\text { World Bank's World } \\
\text { Development } \\
\text { Indicators }\end{array}$ \\
\hline $\begin{array}{l}\text { Log Environmental Policy } \\
\text { Stringency } t-1\end{array}$ & + & $\begin{array}{l}\text { Index on the degree of stringency of } \\
\text { environmental policy instruments } \\
\text { mainly related to climate and air } \\
\text { pollution ( } 0=\text { 'not' stringent; } 6=\text { most } \\
\text { stringent) }\end{array}$ & $\begin{array}{l}\text { OECD Environmental } \\
\text { Policy Stringency } \\
\text { Index }\end{array}$ \\
\hline $\begin{array}{l}\text { Log Labour Market Efficiency } \\
t-1\end{array}$ & - & $\begin{array}{l}\text { Labour Market Efficiency, } 1-7 \text { (best): } \\
\text { Index taking into account the following } \\
\text { aspects: cooperation in labour-employer } \\
\text { relations, flexibility of wage } \\
\text { determination, hiring and firing } \\
\text { practices, redundancy costs, effects of } \\
\text { taxation of incentives to work, pay and } \\
\text { productivity and other related factors }\end{array}$ & $\begin{array}{l}\text { World Economic } \\
\text { Forum Global } \\
\text { Competitiveness Index }\end{array}$ \\
\hline Log Inflation $t-1$ & + & Inflation, consumer prices (annual \%) & $\begin{array}{l}\text { World Bank's World } \\
\text { Development } \\
\text { Indicators }\end{array}$ \\
\hline & B. 1 & eral Host-Home Country Variables & \\
\hline Distance $t-1$ & - & $\begin{array}{l}\text { Geographic distance between the host } \\
\text { and home country }\end{array}$ & CEPII database \\
\hline IIAs $t-1$ & - & International Investment Treaties & OECD IIA database \\
\hline RTAs $t-1$ & - & $\begin{array}{l}\text { Regional Trade Agreements (RTAs) } \\
\text { including information on the type of } \\
\text { RTA (e.g. FTA, PTA, CU, CM, EUN) }\end{array}$ & Baier et al. (2014) \\
\hline DTTs $t-1$ & $+/-$ & Double Taxation Treaties & $\begin{array}{l}\text { Exchange of Tax } \\
\text { Information Portal of } \\
\text { the Global Forum on } \\
\text { Transparency and } \\
\text { OECD }\end{array}$ \\
\hline \multicolumn{4}{|c|}{ Panel C. Affiliate Firm-Level Variables } \\
\hline Log Affiliate's Fixed Assets $t-1$ & + & Affiliate's Fixed assets & ORBIS database \\
\hline $\begin{array}{l}\text { Log Affiliate's Liquidity Ratio } \\
t-1\end{array}$ & - & $\begin{array}{l}\text { Affiliate's ratio of current assets to } \\
\text { current liabilities }\end{array}$ & $\begin{array}{l}\text { Authors' calculation } \\
\text { using ORBIS database }\end{array}$ \\
\hline Log Affiliate's RoA $t-1$ & - & $\begin{array}{l}\text { Affiliate's ratio of EBITDA/Total } \\
\text { Assets }\end{array}$ & $\begin{array}{l}\text { Authors' calculation } \\
\text { using ORBIS database }\end{array}$ \\
\hline
\end{tabular}




\begin{tabular}{|c|c|c|c|}
\hline $\begin{array}{l}\text { Other Affiliates in the Same } \\
\text { Host Country Dummy t-1 }\end{array}$ & + & $\begin{array}{l}\text { A dummy taking a value of } 1 \text { when } \\
\text { another affiliate operates in the same } \\
\text { host country as the affiliate, and } 0 \\
\text { otherwise }\end{array}$ & $\begin{array}{l}\text { Authors' calculation } \\
\text { using ORBIS database }\end{array}$ \\
\hline $\begin{array}{l}\text { Same Sector as Parent's Core } \\
\text { Sector Dummy } t-1\end{array}$ & - & $\begin{array}{l}\text { A dummy taking a value of } 1 \text { when an } \\
\text { affiliate operates in the same save } 4- \\
\text { digit level NAICS sector as its parent } \\
\text { (core sector), and } 0 \text { otherwise }\end{array}$ & $\begin{array}{l}\text { Authors' calculation } \\
\text { using ORBIS database }\end{array}$ \\
\hline \multicolumn{4}{|c|}{ Panel D. Economic Group Firm-Level Variables } \\
\hline $\begin{array}{l}\text { Log Economic Group's Total } \\
\text { Assets } t-1\end{array}$ & + & $\begin{array}{l}\text { Economic group's total assets } \\
\text { (consolidated) }\end{array}$ & ORBIS database \\
\hline $\begin{array}{l}\text { Log Economic Group's } \\
\text { Liquidity Ratio t-1 }\end{array}$ & $+/-$ & $\begin{array}{l}\text { Economic group's ratio of current assets } \\
\text { to current liabilities }\end{array}$ & $\begin{array}{l}\text { Authors' calculation } \\
\text { using ORBIS database }\end{array}$ \\
\hline Log Economic Group's RoA $t-1$ & $+/-$ & $\begin{array}{l}\text { Economic group's ratio of } \\
\text { EBITDA/Total Assets }\end{array}$ & $\begin{array}{l}\text { Authors' calculation } \\
\text { using ORBIS database }\end{array}$ \\
\hline $\begin{array}{l}\text { Log Economic Group's } \\
\text { Solvency Ratio } t-1\end{array}$ & - & $\begin{array}{l}\text { Economic group's ratio of shareholders' } \\
\text { funds to total assets }\end{array}$ & $\begin{array}{l}\text { Authors' calculation } \\
\text { using ORBIS database }\end{array}$ \\
\hline $\begin{array}{l}\text { Economic Group's No. of } \\
\text { Sectors Covered } t-1\end{array}$ & + & $\begin{array}{l}\text { Number of 4-digit NAICS sectors in } \\
\text { which the economic group operates }\end{array}$ & $\begin{array}{l}\text { Authors' calculation } \\
\text { using ORBIS database }\end{array}$ \\
\hline $\begin{array}{l}\text { Log Economic Group's } \\
\text { Internationalisation Level t-1 }\end{array}$ & $+/-$ & $\begin{array}{l}\text { The share of the number of foreign } \\
\text { affiliates to all affiliates covered in the } \\
\text { economic group }\end{array}$ & $\begin{array}{l}\text { Authors' calculation } \\
\text { using ORBIS database }\end{array}$ \\
\hline $\begin{array}{l}\text { Log Economic Group's No. of } \\
\text { Countries Covered t }-1\end{array}$ & $+/-$ & $\begin{array}{l}\text { Number of countries in which the } \\
\text { economic group operates }\end{array}$ & $\begin{array}{l}\text { Authors' calculation } \\
\text { using ORBIS database }\end{array}$ \\
\hline
\end{tabular}




\section{Estimation results}

Table 4 reports the least squares estimates of Equation (1). ${ }^{25}$ Column 1 shows those corresponding to a baseline specification, in which a set of core policy factors encountered in the FDI literature outlined earlier is controlled for, together with a set of controls for affiliate firm and economic group characteristics, following in particular Norbäck et al. (2015) and Berry (2011). Additional policy variables are then incorporated, notably the stringency of environmental policies, education, labour market efficiency and inflation to test if the baseline estimates remain robust when these factors are controlled for (Columns 2-4).

\subsection{Role of host country factors}

According to the specification in Column 4, which includes a full set of policy variables as well as relevant controls, several policies explored in the FDI literature influence MNE divestment decisions. For example, unit labour costs (ULCs), trade openness, applied average tariff rates, real exchange rate volatility, level of control of corruption, labour market efficiency and environmental policy stringency are found to be statistically significant and consistent across the specifications presented in Table 4. They are described in more detail below.

ULCs are defined as the average cost of labour per unit of output produced (that is, the ratio of total nominal labour compensation per hour worked to the volume of output per hour worked). They are often used as a proxy for countries' international competitiveness but care needs to be taken in their interpretation. ${ }^{26}$ Higher ULCs are associated with a higher foreign divestment probability, ceteris paribus. For example, a $10 \%$ increase in a country's ULCs is associated with an increase in foreign divestment probability of 3 percentage points, on average. ${ }^{27}$ This finding is consistent with the FDI literature that generally finds that higher wages or total labour costs are, on average, associated with lower FDI inflows (e.g. Bellak, et al. 2008, Cheng and Kwan, 2000, Nicoletti et al., 2003). Thus, lower FDI inflows due to a loss of international competitiveness can be compounded by divestments.

\footnotetext{
${ }^{25}$ The sample includes all foreign-owned firms that were never divested throughout the period and those that were divested at least once until the year in which they were divested for the first time.

${ }^{26}$ Because the measures are based on national currencies, they will not be able to capture direct increases in competitiveness that may, for example, come through a currency devaluation. In addition, ULCs can fall due to drops in total output and labour input during economic downturns. Moreover, ULCs only consider labour costs and not changes in the cost of other inputs, including capital. Note, too, that countries can remain competitive in the export of high quality goods and services where demand is relatively price inelastic even with relatively high ULCs. See the OECD (2018c) for a discussion.

${ }^{27}$ This result is obtained by multiplying the estimated coefficient on the variable of interest by the natural $\log$ of the increase in that variable. For example, in this case, it would be $0.318 * \ln (1.1)=0.03$. This and the following comparisons are ceteris paribus.
} 
Table 4. Estimation results: Drivers of divestment

\begin{tabular}{|c|c|c|c|c|c|c|}
\hline & (1) & $(2)$ & (3) & (4) & $(5)$ & (6) \\
\hline VARIABLES & Divestment & Divestment & Divestment & Divestment & Divestment & Divestment \\
\hline \multicolumn{7}{|c|}{ Panel A. Host Country Factors } \\
\hline \multirow[t]{2}{*}{ Log GDP t-1 } & $-0.1760^{*}$ & $-0.4590^{* *}$ & $-0.4840^{* *}$ & $-0.7010^{* * *}$ & - & - \\
\hline & $(0.0997)$ & $(0.1800)$ & $(0.2050)$ & $(0.2440)$ & - & - \\
\hline \multirow[t]{2}{*}{ Log GDP pc t-1 } & $0.1780^{*}$ & $0.4040^{* *}$ & $0.5100^{* * *}$ & $0.6620^{* * *}$ & - & - \\
\hline & $(0.0965)$ & $(0.1670)$ & $(0.1890)$ & $(0.2190)$ & - & - \\
\hline \multirow[t]{2}{*}{ Log Real Exchange Rate t-1 } & -0.0232 & 0.0249 & 0.0049 & -0.0682 & - & - \\
\hline & $(0.0284)$ & $(0.0339)$ & $(0.0343)$ & $(0.0476)$ & - & - \\
\hline \multirow[t]{2}{*}{ Log Real Exchange Rate Variability t-1 } & $0.0034^{* *}$ & 0.0030 & $0.0040^{*}$ & $0.0056^{\star *}$ & - & - \\
\hline & $(0.0017)$ & $(0.0023)$ & $(0.0024)$ & $(0.0025)$ & - & - \\
\hline \multirow[t]{2}{*}{ Log Trade-to-GDP t-1 } & $0.0376^{* * *}$ & $0.0747^{\star * *}$ & $0.0719^{* * *}$ & $0.0642^{* * *}$ & - & - \\
\hline & $(0.0123)$ & $(0.0160)$ & $(0.0162)$ & $(0.0180)$ & - & - \\
\hline \multirow[t]{2}{*}{ Log Unit Labour Costs, Total t-1 } & $0.1380^{* * *}$ & $0.2280^{\star * *}$ & $0.2260^{* * *}$ & $0.3180^{* * *}$ & - & - \\
\hline & $(0.0293)$ & $(0.0547)$ & $(0.0600)$ & $(0.0913)$ & - & - \\
\hline \multirow[t]{2}{*}{ Log Tax rate t-1 } & -0.0040 & -0.00334 & 0.0115 & 0.0060 & - & - \\
\hline & $(0.0129)$ & $(0.0306)$ & $(0.0317)$ & $(0.0491)$ & - & - \\
\hline \multirow{2}{*}{ Log Applied Trade Tariff Rate t-1 } & $0.0287^{* * *}$ & $0.0585^{\star * *}$ & $0.0491^{* * *}$ & $0.0574^{* * *}$ & - & - \\
\hline & $(0.0072)$ & $(0.0169)$ & $(0.0175)$ & $(0.0211)$ & - & - \\
\hline \multirow[t]{2}{*}{ Log Time to Trade $\mathrm{t}-1$} & -0.0278 & -0.0229 & -0.0109 & -0.0273 & - & - \\
\hline & $(0.0193)$ & $(0.0235)$ & $(0.0248)$ & $(0.0269)$ & - & - \\
\hline \multirow[t]{2}{*}{ Log Quality of Overall Infrastructure t-1 } & -0.0019 & -0.0224 & $-0.0342^{* *}$ & -0.0201 & - & - \\
\hline & $(0.0103)$ & $(0.0159)$ & $(0.0166)$ & $(0.0202)$ & - & - \\
\hline \multirow[t]{2}{*}{ Log Corruption 1 (TI) t-1 } & $-0.0478^{\star \star *}$ & $-0.0571^{\star * *}$ & $-0.0836^{\star \star *}$ & $-0.0877^{\star \star *}$ & - & . \\
\hline & $(0.0148)$ & $(0.0192)$ & $(0.0197)$ & $(0.0210)$ & - & - \\
\hline \multirow[t]{2}{*}{ Log Political Stability } & $-0.0109^{\star \star *}$ & $-0.0269^{\star * *}$ & $-0.0152^{* *}$ & -0.0120 & & \\
\hline & $(0.0037)$ & $(0.0069)$ & $(0.0074)$ & $(0.0076)$ & & \\
\hline \multirow[t]{2}{*}{ Log Environmental Policy Stringency $\mathrm{t}-1$} & - & $0.0491^{* * *}$ & $0.0453^{\star * *}$ & $0.0477^{* * *}$ & - & - \\
\hline & - & $(0.0138)$ & $(0.0146)$ & $(0.0147)$ & - & - \\
\hline \multirow[t]{2}{*}{ Log Education $\mathrm{t}-1$} & - & - & -0.0862 & -0.2770 & - & - \\
\hline & - & - & $(0.1770)$ & $(0.1850)$ & - & - \\
\hline
\end{tabular}

DRIVERS OF DIVESTMENT DECISIONS OF MULTINATIONAL ENTERPRISES - A CROSS-COUNTRY FIRM-LEVEL PERSPECTIVE 


\begin{tabular}{|c|c|c|c|c|c|c|}
\hline \multirow[t]{2}{*}{ Log WEF Labour Market Efficiency t-1 } & - & - & $-0.2230^{\star \star *}$ & $-0.1960^{* \star *}$ & - & - \\
\hline & - & - & $(0.0465)$ & $(0.0481)$ & - & . \\
\hline \multirow[t]{2}{*}{ Log Inflation t-1 } & - & - & - & -0.0009 & - & - \\
\hline & - & - & - & $(0.0016)$ & - & 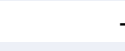 \\
\hline \multicolumn{7}{|c|}{ Panel B. Bilateral Host-Home Country Factors } \\
\hline \multirow[t]{2}{*}{ Log Distance } & $-0.1130^{* * *}$ & $-0.1240^{* * *}$ & $-0.1240^{\star * \star}$ & $-0.1260^{* * *}$ & $-0.0972^{\star * *}$ & - \\
\hline & $(0.0039)$ & $(0.0044)$ & $(0.0044)$ & $(0.0046)$ & $(0.0032)$ & 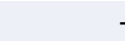 \\
\hline \multirow[t]{2}{*}{$\| A t-1$} & -0.0066 & -0.0057 & -0.0056 & -0.0018 & 0.0023 & $0.0179^{* \star \star}$ \\
\hline & $(0.0045)$ & $(0.0051)$ & $(0.0051)$ & $(0.0051)$ & $(0.0041)$ & $(0.0044)$ \\
\hline \multirow[t]{2}{*}{ RTA t-1 } & $-0.0670^{* * *}$ & $-0.0715^{\star \star \star}$ & $-0.0715^{\star \star *}$ & $-0.0722^{* \star *}$ & $-0.0917^{\star * *}$ & $-0.1040^{\star * \star}$ \\
\hline & $(0.0062)$ & $(0.0070)$ & $(0.0070)$ & $(0.0071)$ & $(0.0057)$ & $(0.0064)$ \\
\hline \multirow[t]{2}{*}{ DTT t-1 } & $0.0593^{* \star *}$ & $0.0630^{\star * \star}$ & $0.0633^{\star \star \star}$ & $0.0634^{* * *}$ & $0.0401^{* * *}$ & $0.0080^{* *}$ \\
\hline & $(0.0055)$ & $(0.0062)$ & $(0.0062)$ & $(0.0064)$ & $(0.0036)$ & $(0.0036)$ \\
\hline \multicolumn{7}{|c|}{ Panel C. Affiliate Firm-Level Factors } \\
\hline \multirow[t]{2}{*}{ Log Affiliate's Fixed Assets t-1 } & $-7.64 \mathrm{e}-06$ & $5.50 \mathrm{e}-05$ & $5.65 \mathrm{e}-05$ & $-2.61 e-05$ & 0.0001 & $0.0006^{\star \star}$ \\
\hline & $(0.0003)$ & $(0.0004)$ & $(0.0004)$ & $(0.0004)$ & $(0.0003)$ & $(0.0003)$ \\
\hline \multirow[t]{2}{*}{ Log Affiliate's Liquidity Ratio t-1 } & -0.0007 & -0.0003 & -0.0003 & -0.0003 & -0.0003 & $4.20 \mathrm{e}-05$ \\
\hline & $(0.0009)$ & $(0.0010)$ & $(0.0010)$ & $(0.0010)$ & $(0.0007)$ & $(0.0008)$ \\
\hline \multirow[t]{2}{*}{ Log Affiliate's RoA t-1 } & -0.0008 & -0.0003 & -0.0002 & -0.0003 & $-0.0011^{* *}$ & $-0.0013^{* \star}$ \\
\hline & $(0.0007)$ & $(0.0007)$ & $(0.0007)$ & $(0.0007)$ & $(0.0005)$ & $(0.0006)$ \\
\hline \multirow[t]{2}{*}{ Other Affiliates in the Same Host Country Dummy t-1 } & $-0.0053^{\star * *}$ & $-0.0063^{* \star \star}$ & $-0.0063^{* \star *}$ & $-0.0068^{* \star *}$ & -0.00177 & $0.00765^{\star \star \star}$ \\
\hline & $(0.0020)$ & $(0.0022)$ & $(0.0022)$ & $(0.0022)$ & $(0.0016)$ & $(0.00159)$ \\
\hline \multirow[t]{2}{*}{ Same Sector as Parent's Core Sector Dummy t-1 } & -0.0049 & -0.0027 & -0.0027 & -0.0027 & -0.00351 & -0.00230 \\
\hline & $(0.0040)$ & $(0.0040)$ & $(0.0040)$ & $(0.0040)$ & $(0.0031)$ & $(0.0031)$ \\
\hline \multicolumn{7}{|c|}{ Panel D. Economic Group Firm-Level Factors } \\
\hline \multirow[t]{2}{*}{ Log Economic Group's Total Assets t-1 } & $0.00530^{* * *}$ & $0.0058^{* * *}$ & $0.0058^{\star * *}$ & $0.0058^{\star * *}$ & $0.0058^{\star * *}$ & $0.0050^{\star * \star}$ \\
\hline & $(0.0009)$ & $(0.0010)$ & $(0.0010)$ & $(0.0010)$ & $(0.0008)$ & $(0.0008)$ \\
\hline \multirow[t]{2}{*}{ Log Economic Group's Liquidity Ratio t-1 } & $0.0074^{* * *}$ & $0.0076^{* \star \star}$ & $0.0075^{\star \star \star}$ & $0.0079^{* * *}$ & $0.0081^{* * *}$ & $0.0082^{* \star *}$ \\
\hline & $(0.0021)$ & $(0.0023)$ & $(0.0023)$ & $(0.0023)$ & $(0.0016)$ & $(0.0015)$ \\
\hline \multirow[t]{2}{*}{ Log Economic Group's RoA t-1 } & 0.0015 & 0.0019 & 0.0020 & 0.0021 & $0.0030^{* *}$ & $0.0030^{* *}$ \\
\hline & $(0.0015)$ & $(0.0017)$ & $(0.0016)$ & $(0.0017)$ & $(0.0012)$ & $(0.0012)$ \\
\hline \multirow[t]{2}{*}{ Log Economic Group's Solvency Ratio t-1 } & -0.0025 & $-0.0031^{*}$ & $-0.0031^{*}$ & -0.0030 & -0.0014 & $-0.0045^{\star * \star}$ \\
\hline & $(0.0017)$ & $(0.0019)$ & $(0.0019)$ & $(0.0019)$ & $(0.0014)$ & $(0.0015)$ \\
\hline
\end{tabular}




\begin{tabular}{|c|c|c|c|c|c|c|}
\hline \multirow{2}{*}{ Log Economic Group's No. of Sectors Covered t-1 } & 0.0018 & 0.0013 & 0.0012 & 0.0020 & -0.0009 & 0.0029 \\
\hline & $(0.0032)$ & $(0.0034)$ & $(0.0034)$ & $(0.0034)$ & $(0.0026)$ & $(0.0026)$ \\
\hline \multirow[t]{2}{*}{ Log Economic Group's Internationalisation Level t-1 } & $0.0304^{\star * *}$ & $0.0351^{\star * *}$ & $0.0350^{\star * *}$ & $0.0348^{* * *}$ & $0.0299^{\star * *}$ & $0.0223^{\star * *}$ \\
\hline & $(0.0038)$ & $(0.0042)$ & $(0.0042)$ & $(0.0043)$ & $(0.0031)$ & $(0.0033)$ \\
\hline \multirow[t]{2}{*}{ Log Economic Group's No. of Countries Covered t-1 } & -0.0007 & -0.0015 & -0.0014 & -0.0020 & $-0.0038^{*}$ & $-0.0114^{\star * *}$ \\
\hline & $(0.0025)$ & $(0.0027)$ & $(0.0027)$ & $(0.0027)$ & $(0.0021)$ & $(0.0022)$ \\
\hline \multicolumn{7}{|c|}{ Panel E. Included Fixed Effects } \\
\hline HOST COUNTRY SECTOR FE & Yes & Yes & Yes & Yes & Yes & No \\
\hline HOST COUNTRY TIME FE & No & No & No & No & Yes & No \\
\hline HOST COUNTRY SECTOR TIME FE & No & No & No & No & No & Yes \\
\hline HOME COUNTRY SECTOR TIME FE & Yes & Yes & Yes & Yes & Yes & Yes \\
\hline Observations & 45,899 & 38,157 & 38,157 & 36,274 & 71,881 & 65,142 \\
\hline R-squared & 0.512 & 0.519 & 0.519 & 0.530 & 0.499 & 0.504 \\
\hline Adjusted R-squared & 0.410 & 0.413 & 0.413 & 0.424 & 0.404 & 0.349 \\
\hline
\end{tabular}

Note: Stars denote statistical significance at: $* * * 99 \%, * * 95 \%, * 90 \%$, respectively. Robust standard errors are clustered by firm. The sample comprises 41 countries listed in Annex A. Robustness checks in columns 7-9, replicating models 4-6, are performed on larger sample of 146 countries for which ownership information is available in ORBIS and can be followed through time in order to verify the sensitivity of results to changes in the country coverage. Information on financial performance and other firm-level characteristics is not available for larger sample of countries, which disallows for an inclusion of time-variant firm-level controls included in Columns 1-6 for the sample of 41 selected OECD and G20 economies.

Source: OECD calculations using ORBIS @ data. 
Meanwhile, higher labour market efficiency as proxied by the World Economic Forum (WEF) Labour Market Efficiency Index, which covers a series of different labour practices for a large set of countries ${ }^{28}$, is also found to reduce the probability of foreign divestment, ceteris paribus. A $10 \%$ increase in a country's labour market efficiency is associated with a reduction in foreign divestment probability of 2 percentage points, on average. Earlier studies testing the influence of labour market flexibility on FDI have accordingly found that lower labour flexibility can act as a deterrent to FDI (Dewit et al., 2003b; Javorcik and Spartareanu, 2005; Görg, 2005).

Other aspects of domestic regulation matter as well: consistent with findings in studies on FDI attraction (e.g. Javorcik and Wei, 2009), better control of corruption, as measured by the Transparency International Corruption Perception Index (CPI) (where 0 means "highly corrupt" and 100 means "very clean"), matters for investment retention, too. ${ }^{29} \mathrm{An}$ improvement by $10 \%$ in a country's level of control of corruption is associated with a reduction in foreign divestment probability of 1 percentage point, on average. ${ }^{30}$

The level of stringency of environmental protection, as measured by the OECD Environmental Policy Stringency Index ${ }^{31}$, is also found to influence foreign divestment probability: a $10 \%$ increase in a country's stringency of environmental protection is associated with an increase in foreign divestment probability of 0.5 percentage points, on average.

In the area of trade, higher trade tariffs are found to be associated with an increased divestment probability. A 10\% increase in a country's tariffs is associated with an increase in foreign divestment probability of 0.5 percentage points, on average. Trade openness itself, measured as the ratio of trade (exports plus imports) to GDP, also increases divestment probability, potentially reflecting the substitutability between trade and FDI as means of serving markets.

Meanwhile, higher tax rates were not consistently found to be a driver of foreign divestments. Being able to resort to accounting techniques that shift profits across borders as well as the use of tax agreements (discussed later) could mean that firms are able to adjust to changes in tax burdens in ways other than through divestment. ${ }^{32}$ Other policies that matter for FDI attraction in the literature, such as the quality of education and infrastructure, for example, were found not to be statistically significant determinants of foreign divestment probabilities. This could be because these aspects are potentially more

\footnotetext{
${ }^{28}$ The Index covers such aspects as cooperation in labour-employer relations, flexibility of wage determination, hiring and firing practices, redundancy costs, effects of taxation on incentives to work, pay and productivity (WEF, 2017).

${ }^{29}$ The average score of countries in the sample is 68 (with Iceland scoring the highest and Russia the lowest), which reflects the overall high level of development in the countries in the sample (primarily OECD and EU economies). Indeed, Western Europe is the highest scoring region on the Index.

${ }^{30}$ Results remain robust when an alternative metric for control of corruption sourced from the World Bank's World Governance Indicators is used.

${ }^{31}$ See Botta and Koźluk (2014) for more information.

${ }^{32}$ In addition, it could also be that the metric used here does not capture the true extent of taxation or tax burden faced by firms. As such, future work could focus on refining the metric (see OECD, 2015b).
} 
difficult to capture in simple country-level variables and that they do not have sufficient variation over time. ${ }^{33}$

Finally, rather than the level of the real exchange rate itself, it is found that it is the exchange rate volatility (calculated as a standard deviation in real exchange rate changes over a three-year period, following Berry, 2013) that matters for divestment decisions; once real exchange rate volatility is controlled for, the real exchange level ceases to be statistically significant. This suggests that volatility incentivises firms to leave, perhaps by making hedging more difficult or costly. ${ }^{34}$

\subsection{Role of firm-level factors}

Certain MNE's economic group-wide considerations are found to be statistically significant determinants of firm divestments, confirming that the parent takes into account the performance of, and the strategic opportunities within, the economic group as a whole when deciding to sell a particular affiliate (e.g. Norbäck et al., 2015; Berry, 2010, 2013; Kogut and Kulatilaka, 1994). For example, affiliates belonging to parents with larger economic groups (in terms of total assets) are divested relatively more frequently than those belonging to firms with smaller groups, which is consistent with earlier studies (e.g. Berry 2010, 2013), and predictions outlined earlier. The internationalisation level of the group, i.e. the share of the foreign affiliates to all affiliates in the group, also increases divestment probability (a 10\% increase in the internationalisation level increases the probability of divestment by 0.3 percentage points). Consistent with other studies, it is also found that parents with higher solvency ratios, defined a as ratio of shareholders' funds to total assets in the group, are less likely to divest. ${ }^{35}$ This confirms that parents may sell affiliates to improve the overall financial health of the group, all else being equal (e.g. Berry, 2010). The affiliate performance, as captured by the affiliate's return on assets (ROA) is also found to be statistically significant and negatively correlated with divestment probability, albeit only in some specifications and is found to have marginal

\footnotetext{
${ }^{33}$ Unlike in the case of an investment decision, a decision to divest takes place in known locations, i.e. countries where a firm has already operated and is familiar with. For example, Boddewyn (1983b) explains this difference between a decision to invest and a decision to divest by adapting the eclectic theory of investment (Dunning, 1979) and highlighting that a firm incorporates firsthand knowledge of actual business prospects in the country in the case of divestments.

${ }^{34}$ Interestingly, once real exchange rate volatility and inflation are controlled for, which could serve as proxies of countries' economic instability, political stability, as measured by the World Banks's Worldwide Governance Indicators, is not statistically significant (see Column 4 in Table 4).

35 At the same time, conditional on the parent's solvency ratio, affiliates belonging to parents with a higher liquidity ratio and ROA are found to be divested more frequently (coefficients are positive and statistically significant). This may suggest that relatively more successful parents undertake divestments, holding debt levels constant. This may be explained by strategic divestments by MNEs (e.g. Markides, 1992, 1995)
} 
economic significance. ${ }^{36}$ It is possible that the effect of this dimension of firm performance on divestment take longer to materialise (see e.g. Blonigen et al., 2014). ${ }^{37}$

Meanwhile, there is not strong evidence that other group-level factors matter in firm divestment decisions. For example, the level of diversification of the economic group, proxied by the number of core sectors in which the group operates, is not found to be a statistically significant predictor of MNE divestment, above and beyond the effect of the company's size. While there is some evidence that the "operational flexibility" provided to the MNE by a wide network of countries covered in its group (Kogut and Kulatilaka, 1994), the effect is small and not confirmed in all specifications. Similarly, there is no evidence that being in the same core sector as the parent (at either 2- or 4 digit NAICS level) influences divestment probability of the affiliate. ${ }^{38}$ The presence of other affiliates of the same parent in the same host country also renders ambiguous results. Considering these findings and the insights from the management literature referred to earlier, it is possible that these strategic firm-specific factors are more difficult to capture in the model and would require further analysis, ${ }^{39}$ or devoted business case studies.

\subsection{Role of international agreements}

Besides the role of general investment climate factors, the specific role of regional trade agreements (RTAs), international investment agreements (IIAs), and Double-Taxation Treaties (DTTs) on firm divestment probability is also considered. This analysis seems particularly timely as the benefits of investment agreements specifically have come under public scrutiny and as several G20 countries have reformed or terminated some of their existing treaties (OECD-UNCTAD, 2018). Most of countries included in the sample are covered by at least one type of such an agreement and many are covered by all three types of treaties. ${ }^{40}$

\footnotetext{
${ }^{36}$ Note that ROA can take negative values, and it is the case in over $20 \%$ of affiliate firms in the sample (but is the case for only 3\% of MNE parents). Therefore, an alternative specification is tested where the variables that can take negative values (i.e. the affiliate's and economic group's ROA as well as the economic group's solvency ratio) are included in regressions in levels (rather than logs), among others. The relative size and significance of the coefficients on policy variables does not change significantly while the coefficient on ROA loses significance. Results are available from the authors upon request.

${ }^{37}$ Additional lags of this variable would need to be added to test this. Unfortunately, the dataset does not have a sufficiently long span to do so.

${ }^{38}$ This metric could serve as a proxy of "relatedness" described in the business literature (see e.g. Brauer, 2006). For example, Berry (2013) explores the role of "relatedness" of an affiliate and parent by considering if an affiliate operates in the same 3-digit SIC business line as the core business of the parent firm.

${ }^{39}$ For example, the sectoral relationship between the affiliate and the parent could be tested further taking into account the relationships between firms' secondary and tertiary sectors. Similarly, an additional control could be considered for affiliates that are "horizontal" or "vertical" in nature, i.e. operate in the same or different sector than a parent and provide or not inputs to the parent's sector (e.g. following the methodology developed by Alfaro and Charlton, 2009). One could also compare the characteristics of the affiliate relative to the whole economic group or the industry's average.

${ }^{40}$ The EU accounts for a majority of RTAs in the sample given that most of the firms are those operating within the European Union. Following the classification by Baier et al. (2014) and Kohl et al. (2016), the EU is later classified as a Deep RTA.
} 
Table 4 also reported results of regressions on the effect of RTAs, IIAs, and DTTs on the probability of foreign divestment, including specifications where unobserved time-varying host-country and host-country-sector characteristics are controlled for through relevant fixed effects (Columns 5-6), which could not be controlled for in earlier regressions, considering also the role of individual host country factors (Columns 1-4).

As shown in Table 4, for the OECD and G20 economies, the effect of having an RTA is statistically significant and is found to systematically reduce the probability of foreign divestment across all specifications. Specifically, existence of an RTA between a pair of countries of an affiliate and its parent reduces the probability of foreign divestment by 7 $10 \%$, all else being equal, depending on the specification. ${ }^{41}$ Meanwhile, the overall effect of IIAs appears mixed and relatively small. The effect of DTTs is also small. The variable of IIAs includes both bilateral investment treaties and RTAs with investment chapters. As such, it is found that on average, and controlling for the presence of other agreements, these types of provisions do not appear to have a significant impact on the divestment probability by firms located in 41 selected OECD and G20 economies studied here. The following section presents a series of robustness checks that aim to corroborate the results presented here.

\footnotetext{
${ }^{41}$ Column 6, showing that the presence of an RTA reduces the probability of foreign divestment by $10 \%$, represents the most stringent model that allows for a study of the effect of bilateral host-home country factors on divestment probability.
} 


\section{Robustness checks and heterogeneous effects of international} agreements

Besides testing alternative models and the sensitivity of the estimations to the inclusion of different control variables (see Table 4 in the earlier section), Table 5 below presents a series of additional robustness checks performed to corroborate the results on the effects of international agreements on firm divestment probability.

First, the role that international agreements play can differ significantly for different types of countries. Indeed, some of these agreements, notably IIAs, are much more frequently used by less developed economies. ${ }^{42}$ As such, the original sample of 41 selected OECD and G20 economies is extended to 146 countries globally for which the ORBIS dataset contains relevant ownership information to test whether results differ when a larger group of advanced and developing economies is considered. ${ }^{43}$ Table 5 reports results of these regressions where Columns 1-3 correspond to regressions 5-6 in Table 4. The findings for RTAs and DTTs do not change. In particular, the presence of an RTA between a host country of the affiliate and the home country of the parent is associated with a 5-7\% lower probability of divestment of that affiliate. Meanwhile, the effect of IIAs changes as the presence of IIAs reduces foreign divestment probability in the wider sample that includes less developed economies. Specifically, existence of an IIA between a home country of the parent and the host country of the affiliate is associated with a $2 \%$ decrease in foreign divestment probability of the parent firm, all else being equal. The results are robust when standard errors are clustered at the firm- as well as host-home country pair level, at which the data varies for the bilateral factors, and international agreements in particular.

To account for further sources of unobserved heterogeneity, an additional robustness check is conducted by testing an alternative specification described in Equation 2 (reported in Columns 5-6 in Table 5). ${ }^{44}$ The effect of a presence of an RTA on foreign divestment probability remains consistent and statistically significant in all specifications, in particular when standard errors are clustered at the firm-level. The effect of IIAs and DTTs meanwhile ceases to be statistically significant. This can point to limited variation in the sample; but it is also possible that different elements of these agreements have opposite effects, causing an average effect to be insignificant. ${ }^{45}$ This highlights the importance of studying possible heterogeneous effects.

\footnotetext{
42 For example, according to the data in UNCTAD's database of international investment agreements that includes information on IIAs signed and in force globally, as of 2019, 64\% of IIAs worldwide were signed by countries outside of the OECD and G20 (with the remaining 36\% being in the sample used in this paper).

${ }^{43}$ Please note that information on financial performance or other firm characteristics is mostly unavailable for this group of countries. Hence, it is not possible to control for a set of time-variant affiliate-firm and economic group's level characteristics as was done in the baseline regressions for the sample of selected OECD and G20 countries. This is also the reason why the paper focuses on the sample of OECD and G20 countries for which ORBIS has a better coverage.

${ }^{44}$ Columns 5-6 show the results of the same estimation while Column 6 additionally restricts the sample to firms that have not changed their foreign-owned parent between 2007-20014 to control for any further ownership changes throughout the period.

${ }^{45}$ For example, Blonigen et al. (2014) find that while the aggregate effect of DTTs on firm investment decisions is insignificant, their different provisions have positive effects.
} 
Table 5. Effect of international integration agreements: Robustness checks with alternative sample and specification

\begin{tabular}{|c|c|c|c|c|c|}
\hline & \multicolumn{3}{|c|}{ Alternative Sample } & \multicolumn{2}{|c|}{ Alternative Sample \& Specification } \\
\hline & (1) & (2) & (3) & (4) & (5) \\
\hline VARIABLES & Divestment & Divestment & Divestment & $\Delta$ Divestment & $\Delta$ Divestment \\
\hline \multicolumn{6}{|c|}{ Panel A. Robustness Checks } \\
\hline$\| A t-1$ & -0.0229 & -0.0050 & -0.0160 & -0.0093 & -0.0115 \\
\hline Cluster Firm & $(0.0028)^{\star \star *}$ & $(0.0014)^{\star * *}$ & $(0.0015)^{\star * *}$ & $(0.0077)$ & $(0.0090)$ \\
\hline Cluster Host-Home & $(0.0107)^{\star *}$ & $(0.0092)$ & $(0.0122)$ & $(0.0127)$ & $(0.0151)$ \\
\hline RTA t-1 & -0.0452 & -0.0936 & -0.0643 & -0.0205 & -0.0274 \\
\hline Cluster Firm & $(0.0034)^{\star \star \star}$ & $(0.0017)^{\star * *}$ & $(0.00175)^{\star * *}$ & $(0.0107)^{*}$ & $(0.0122)^{\star *}$ \\
\hline Cluster Host-Home & $(0.0120)^{\star * *}$ & $(0.0147)^{\star * *}$ & $(0.0165)^{\star * *}$ & $(0.0164)$ & $(0.0185)$ \\
\hline DTT t-1 & 0.0354 & 0.0210 & 0.0051 & 0.0004 & -0.0006 \\
\hline Cluster Firm & $(0.0023)^{\star \star \star}$ & $(0.0013)^{\star * *}$ & $(0.0013)^{\star * *}$ & $(0.0056)$ & $(0.0064)$ \\
\hline Cluster Host-Home & $(0.0106)^{\star \star \star}$ & $(0.0089)^{\star *}$ & $(0.0084)$ & $(0.0095)$ & $(0.0110)$ \\
\hline \multicolumn{6}{|c|}{ Panel B. Included Controls \& Fixed Effects } \\
\hline $\begin{array}{l}\text { TIME VARIANT HOST COUNTRY } \\
\text { FACTORS t-1 }\end{array}$ & Yes & No & No & No & No \\
\hline $\begin{array}{l}\text { TIME INVARIANT HOST-HOME } \\
\text { COUNTRY FACTORS t-1 }\end{array}$ & Yes & No & No & Yes & Yes \\
\hline HOST COUNTRY SECTOR FE & No & No & No & Yes & Yes \\
\hline HOME COUNTRY SECTOR FE & No & No & No & Yes & Yes \\
\hline HOST COUNTRY TIME FE & No & Yes & No & No & No \\
\hline HOST COUNTRY SECTOR TIME FE & No & No & Yes & No & No \\
\hline HOME COUNTRY SECTOR TIME FE & Yes & Yes & Yes & No & No \\
\hline Observations & 209,318 & 487,305 & 482,922 & 67,389 & 53,294 \\
\hline R-squared & 0.345 & 0.375 & 0.345 & 0.269 & 0.289 \\
\hline Adjusted R-squared & 0.283 & 0.317 & 0.248 & 0.164 & 0.175 \\
\hline
\end{tabular}

Note: Stars denote statistical significance at: $* * * 99 \%, * * 95 \%, * 90 \%$, respectively. The sample comprises 146 countries for which firm-level ownership information is available in the ORBIS @ $)$ dataset. Columns 1-3 correspond to Equation 1 and show the results of a regression of a foreign divestment variable that is a binary variable that takes a value of 1 if an affiliate $\mathrm{f}$ in a (4-digit NAICS classification) sector $\mathrm{s}$ in a host country c is divested (i.e. ceases to have majority control) by its foreign-owned parent belonging to an economic group e in a home country $\mathrm{h}$ in a given year $\mathrm{t}$, and zero otherwise, controlling for a set of time-variant host country-level and time-invariant bilateral host-home country factors (as reported in Table 4) as well as a set of host country time, host country- sector time and home country sector time fixed effects, depending on the specification. Columns 4-5 correspond to Equation 2 and show the results of a regression of a foreign divestment variable that is a binary variable that takes a value of 1 if an affiliate $\mathrm{f}$ in a (4-digit NAICS classification) sector $\mathrm{s}$ in a host country $\mathrm{c}$ was foreign-owned in 2007 and was divested (i.e. ceases to have majority control) by its foreign parent belonging to an economic group $e$ in a home country $h$ at some point between 2007 and 2014, and zero otherwise $\left(\Delta D_{f s c e h(t)}=D_{f s c e h(2008-2014)}-D_{f s c e h(2007)}\right)$, controlling for a set of time-invariant host-home country pair factors as well as host country sector and home country sector fixed effects, depending on the specification.. Column 6 includes the results of the same specification as Column 5, while additionally limiting the sample to firms that have not changed their foreign-owned parent between 2007-20014 to control for any further ownership changes throughout the period. Robust standard errors are clustered by firm and host-home country pair, respectively.

Source: OECD calculations using ORBIS $\odot$ data.

To illustrate this point, and given the importance of treaty content found in the literature ${ }^{46}$, a further robustness check is undertaken by allowing the effect to vary depending on the character of RTA for which the data are available. For this purpose, RTAs are classified according to their depth as developed by Baier et al. (2014), and the earlier employed RTA

\footnotetext{
${ }^{46}$ For the discussion on the importance of content of PTAs and RTAs, see e.g. Dür et al. (2014), Kohl (2014), Kohl et al. (2016), Baier et al. (2014), Orefice and Rocha (2014), Blyde, Graziano and Volpe Martincus. (2015); the content of IIAs, see e.g. Berger et al. (2011, 2013) and Alschner and Skougarevskiy (2016); and the content of DTTs, Blonigen, Oldenski and Sly (2014).
} 
dummy is nuanced. In particular, RTAs are divided into two groups: Shallow RTAs, covering preferential trade agreements and free trade agreements, and Deep RTAs, covering customs unions, customs markets and economic unions.

Table 6 reports the estimation results using these categories and the various specifications used earlier for both samples. ${ }^{47}$ It is found that the impact of international agreements on firm divestment probability is heterogeneous, depending on the depth of an agreement. Specifically, it is particularly deep RTAs (i.e. economic unions, customs markets and customs unions) that reduce foreign divestment probability. The results are consistent for both samples. Meanwhile, the coefficients on BITs and DTTs remain similar as those in earlier regressions. In the future, a similar exercise could be undertaken differentiating between IIAs and DTTs, depending on their content.

To summarise, the results presented here are consistent with the earlier FDI literature in the reverse scenario, which generally finds a positive relationship between the presence of an RTA, including a deep RTA, and FDI flows into the host economy or MNE presence (e.g. number of foreign affiliates operating in the host country). The more mixed results for the impact of IIAs and DTTs are also consistent with the earlier literature.

\footnotetext{
${ }^{47}$ In particular, Columns 1-6 show the results of the estimation described in Equation 1 on both samples (Columns 1-3 for 41 selected OECD and G20 economies and Columns 4-8 for all 146 countries) and Columns 7-8 show the results of the estimation described in Equation 2 for the full sample of 146 countries.
} 
Table 6. Effect of international integration agreements: Heterogeneous effects

\begin{tabular}{|c|c|c|c|c|c|c|c|c|}
\hline & \multicolumn{3}{|c|}{ Benchmark Sample } & \multicolumn{3}{|c|}{ Alternative Sample } & \multicolumn{2}{|c|}{ Alternative Sample and Specification } \\
\hline & (1) & (2) & (3) & (4) & $(5)$ & (6) & (7) & (8) \\
\hline VARIABLES & Divestment & Divestment & Divestment & Divestment & Divestment & Divestment & $\Delta$ Divestment & $\Delta$ Divestment \\
\hline \multicolumn{9}{|c|}{ Panel A. Heterogeneous Effects } \\
\hline IIA t-1 (2007) & -0.0025 & 0.0021 & 0.0175 & -0.0215 & -0.0012 & -0.0094 & -0.0088 & -0.0110 \\
\hline Cluster Firm & $(0.0051)$ & $(0.0041)$ & $(0.0044)^{\star * *}$ & $(0.0028)^{\star * *}$ & $(0.0014)$ & $(0.0015)^{\star * *}$ & $(0.0077)$ & $(0.0090)$ \\
\hline Cluster Host-Home & $(0.0167)$ & $(0.0176)$ & $(0.0195)$ & $(0.0103)^{* *}$ & $(0.0088)$ & $(0.0112)$ & $(0.0125)$ & $(0.0150)$ \\
\hline Shallow RTA t-1 (2007) & -0.0163 & -0.0075 & -0.0308 & 0.0051 & -0.0683 & -0.0201 & -0.0072 & -0.0152 \\
\hline Cluster Firm & $(0.0129)$ & $(0.0093)$ & $(0.0097)^{\star * *}$ & $(0.0052)$ & $(0.0021)^{\star * *}$ & $(0.0021)^{\star \star *}$ & $(0.0125)$ & $(0.0142)$ \\
\hline Cluster Host-Home & $(0.0247)$ & $(0.0205)$ & $(0.0203)$ & $(0.0149)$ & $(0.0125)^{\star \star \star}$ & $(0.0110)^{*}$ & $(0.0182)$ & (0.0208) \\
\hline Deep RTA t-1 (2007) & -0.0781 & -0.1020 & -0.1120 & -0.0532 & -0.1060 & -0.0860 & -0.0394 & -0.0455 \\
\hline Cluster Firm & $(0.0073)^{\star * *}$ & $(0.0060)^{\star * *}$ & $(0.0066)^{\star * *}$ & $(0.0034)^{\star * *}$ & $(0.0019)^{\star * *}$ & $(0.0020)^{\star \star *}$ & $(0.0129)^{\star * *}$ & $(0.0149)^{* * *}$ \\
\hline Cluster Host-Home & $(0.0270)^{* * *}$ & $(0.0262)^{\star * *}$ & $(0.0317)^{\star * *}$ & $(0.0130)^{\star * *}$ & $(0.0166)^{\star * *}$ & $(0.0201)^{\star * *}$ & $(0.0200)^{\star *}$ & $(0.0221)^{* *}$ \\
\hline DTT t-1 (2007) & 0.0616 & 0.0372 & 0.0053 & 0.0342 & 0.0193 & 0.0024 & -0.0002 & -0.0013 \\
\hline Cluster Firm & $(0.0064)^{\star * *}$ & $(0.0036)^{\star * *}$ & $(0.0036)$ & $(0.0023)^{\star * *}$ & $(0.0013)^{\star * \star}$ & $(0.0013)^{*}$ & $(0.0056)$ & $(0.00640)$ \\
\hline Cluster Host-Home & $(0.0163)^{\star * *}$ & $(0.0123)^{\star \star *}$ & $(0.0086)$ & $(0.0106)^{\star * *}$ & $(0.0087)^{\star *}$ & $(0.0082)$ & $(0.0095)$ & $(0.0110)$ \\
\hline \multicolumn{9}{|c|}{ Panel B. Included Controls \& Fixed Effects } \\
\hline TIME VARIANT HOST COUNTRY FACTORS $\mathrm{t}-1$ & Yes & No & No & Yes & No & No & No & No \\
\hline TIME VARIANT AFFILIATE FIRM FACTORS t-1 & Yes & Yes & Yes & No & No & No & No & No \\
\hline TIME VARIANT ECONOMIC GROUP FACTORS t-1 & Yes & Yes & Yes & No & No & No & No & No \\
\hline HOST COUNTRY SECTOR FE & No & No & No & No & No & No & Yes & Yes \\
\hline HOME COUNTRY SECTOR FE & No & No & No & No & No & No & Yes & Yes \\
\hline HOST COUNTRY TIME FE & No & Yes & No & No & Yes & No & No & No \\
\hline HOST COUNTRY SECTOR TIME FE & No & No & Yes & No & No & Yes & No & No \\
\hline HOME COUNTRY SECTOR TIME FE & Yes & Yes & Yes & Yes & Yes & Yes & No & No \\
\hline Observations & 36,274 & 71,881 & 65,142 & 209,318 & 487,305 & 482,922 & 67,389 & 53,294 \\
\hline R-squared & 0.532 & 0.503 & 0.507 & 0.347 & 0.376 & 0.348 & 0.269 & 0.289 \\
\hline Adjusted R-squared & 0.426 & 0.409 & 0.353 & 0.285 & 0.319 & 0.252 & 0.164 & 0.176 \\
\hline
\end{tabular}

Note: Stars denote statistical significance at: $* * * 99 \%, * * 95 \%, * 90 \%$, respectively. RTAs are divided into two groups following Baier et al. (2014): Shallow RTAs covering preferential trade agreements (PTAs) and free trade agreements and Deep RTAs, covering customs unions (CU), customs markets (CM) and economic unions (EUN). Shallow RTAs is a binary variable that takes a value of 1 if there is a shallow RTA (i.e. PTA or FTA) between the host country of the affiliate $\mathrm{f}$ and the home country of its economic group's parent e in time $t$ and 0 otherwise. Deep RTAs is a binary variable that takes a value of 1 if there is a deep RTA (i.e. CU, CM, EUN) between the host country of the affiliate f and the home country of its economic group's parent e in time $t$ and 0 otherwise. Columns 1-6 show the results of the baseline specification described in Equation 1 and Columns 7-8 the alternative specification described in Equation 2. Note that Columns 1-3 correspond to Columns 4-6 in Table 4, while nuancing the effect of an RTA by dividing it into Deep and Shallow RTA, for the sample of 41 selected OECD and G20 economies. Columns 4-6 follow the same approach, nuancing the effect of an RTA on the sample of 146 countries (i.e. correspond to Columns 1-3 in Table 5). Finally, Columns 7-8 test the new specification on the sample of 146 countries (corresponding to Columns $4-5$ in Table 5). Robust standard errors are clustered by firm and host-home country pair, respectively

Source: OECD calculations using ORBIS $\odot$ data. 


\section{Conclusions, further research and policy implications}

This paper has provided novel cross-country evidence on the importance of foreign divestment by MNEs - a phenomenon that remains understudied and poorly understood. It has shown that foreign divestment is a frequent economic occurrence that affected every fifth foreign-owned affiliate in selected 41 OECD and G20 economies in the period 2007-2014.

It also provided cross-country evidence on various drivers of divestment decisions by MNEs, including firm-, host-country, and bilateral host-home country pair factors, studying a large set of firms operating globally. It finds that several different factors, including policies, matter for MNE divestment decisions; for example, raising unit labour costs, trade openness, applied average tariff rates, real exchange rate volatility, level of control of corruption, labour market efficiency and environmental policy stringency appear to influence firm divestment probability. Several firm-level considerations studied in the management literature, such as the overall size, financial health or the level of internationalisation of the parent's business group, are also found to play a role. Finally, the results also confirm the relevance of international agreements to divestment decisions by MNEs. For example, the existence of an RTA in general, and a deep RTA in particular (e.g. single market or customs union), has been found to be consistently associated with a lower probability of divestment by an MNE. This finding holds true for both developed and developing countries, and may be relevant to the on-going discussions about possible renegotiations of such agreements. The impact of IIAs and DTTs appears less clear, in particular for OECD and G20 economies.

Several tentative policy implications emerge. First, while the role of policies in shaping firm foreign divestment decisions has been virtually unstudied to-date, this paper suggests that public policies can influence MNE divestments. For example, unit labour costs and labour market efficiency are found to be an important determinant of MNE divestments, highlighting the importance of ongoing labour market reforms to maintain competitiveness. Control of corruption also matters for both investment attraction and retention; and political and economic volatility also comes at a price of increased divestment probability, highlighting the critical role of institutional factors. Last but not least, the existence of international economic integration agreements - recently subject to debate in political circles - has been found to significantly influence firm divestment decisions. Notably, affiliates located in countries with which the parent firm's home country has a deep RTA, which includes the EU membership, are significantly less likely to be divested. In addition, higher applied trade tariffs also increase significantly divestment probability. These findings may need to be born in mind during future negotiations on this issue.

Lastly, while investment retention may be an objective that policymakers need to bear in mind to the same extent as investment attraction, policy actions required to reduce the risk of MNE divestments may also clash with other policy objectives. For example, increased environmental stringency is found to increase divestment probability but may need to be pursued on other grounds, including to alter the profile of firms that operate in the economy.

These findings suggest that there is a merit in better understanding firm divestment decisions and their drivers - including differences in factors that influence MNE investment and divestment decisions. These results could be corroborated through further research, including testing of alternative specifications and estimation techniques as well as performing additional robustness checks (e.g. placebo tests). The analysis in this paper focuses on the years 2007-2014 due to data limitations. A possible extension could 
consider, and add, longer sample periods to check if the trends identified here also emerge when a longer term perspective is taken. Improvements could also be made to the variables used, both at the firm- and country-level, to ensure that they meaningfully capture the underlying business and policy dynamics. For example, some of the strategic and corporate factors influencing firm divestment decisions could be explored further, including to reflect better the role of parent-affiliate relations and corporate strategies. Similarly, the role of specific aspects of policies and their design could be explored.

One example of such an avenue for further study is the role of specific provisions of international economic integration agreements, and their differential impact on firm divestment decisions. As both this paper and recent trade literature show, the effects of such treaties can vary significantly depending on their design as well as firm characteristics. As such, further nuancing of the IIA and DTT variables as well as their interaction with different firm characteristics could provide meaningful insights into their role and existence of possible heterogeneous effects. As different elements of these treaties may influence firm decisions in opposite directions, it is possible that the average affect is not statistically significant while "unpacking the box" would provide important insights. The only known study assessing the effect of IIAs on firm behaviour using firm-level data is Egger and Merlo (2012) and it does not differentiate between treaties, depending on their specific provisions. Considering the on-going debate about benefits and costs of such treaties, further evidence on their effects on firms could be particularly pertinent. The availability of rich information on treaty content available in the OECD IIA database and other sources as well as an increasing availability of firm-level data, as used in this paper, could allow such an analysis in the future. 


\section{Bibliography}

Aitken, B. J., and A. E. Harrison (1999), "Do Domestic Firms Benefit from Direct Foreign Investment? Evidence from Venezuela", American Economic Review 89 (3): 605-18.

Aitken, B., Hanson, G., and Harrison, A. (1997). Spillovers, foreign investment and export behaviour. Journal of International Economics, 43, 103-132.

Alam, A. and S.Z.A. Shah, (2013). Determinants of foreign direct investment in OECD member countries, Journal of Economic Studies, Vol. 40(4), pp. 515 - 527

Alfaro, L. and A. Charlton (2009), "Intra-Industry Foreign Direct Investment." American Economic Review 99 (5): 2096-2119.

Alfaro, L. and M. X. Chen (2018). "Selection and Market Reallocation: Productivity Gains from Multinational Production," American Economic Journal: Economic Policy, American Economic Association, Vol. 10(2), 1-38.

Alfaro, L. and M. X. Chen (2012), "Surviving the Global Financial Crisis: Foreign Ownership and Establishment Performance." American Economic Journal: Economic Policy 4, 3, 30-55.

Alfaro, L. and M. X. Chen (2014), "Selection and Market Reallocation: Productivity Gains from Multinational Production." NBER Working Paper 18207.

Alfaro, L., S. Kalemli-Ozcan and V. Volosovych (2007), "Capital Flows in a Globalized World: The Role of Policies and Institutions," NBER Chapters in: Capital Controls and Capital Flows in Emerging Economies: Policies, Practices and Consequences, pages 19-72 National Bureau of Economic Research, Inc.

Alfaro, L., S. Kalemli-Ozcan and V. Volosovych (2008) "Why Doesn't Capital Flow from Rich to Poor Countries? An Empirical Investigation," The Review of Economics and Statistics, MIT Press, vol. 90(2), 347-368.

Alvarez, R. and H. Görg, "Multinationals and Plant Exit: Evidence from Chile," International Review of Economics and Finance 18 (2009):45-51.

Angrist J. (2001), "Estimation of Limited Dependent Variable Models with Dummy Endogenous", Journal of Business and Economic Statistics, Vol.19(1): 17-20.

Angrist J. (2006), "Instrumental Variables Methods in Experimental Criminological Research: What, Why and How", Journal of Experimental Criminology 2: 23-44.

Antràs P. and S. R. Yeaple (2014), "Multinational Firms and the Structure Of International Trade", Handbook of International Economics, Vol 4, 55-130.

Ariu A. (2016), "Crisis-proof services: Why trade in services did not suffer during the 20082009 collapse", Journal of International Economics, Vol. 98, Issue C, 138-149.

Arnold, J. and B. S. Javorcik (2009), "Gifted Kids or Pushy Parents? Foreign Direct Investment and Firm Productivity in Indonesia." Journal of International Economics, 79, 42-53.

Arulampalam W., Devereux M. P. and Liberini F. (2017), "Taxes and the Location of Targets", Oxford University Center for Business Taxation Working Paper Series, 17/04.

Ashraf, A., Herzer, D., and Nunnenkamp, P. (2015), "The effects of greenfield FDI and crossborder M\&As on total factor productivity", The World Economy, 39(11), 1728-1755.

Asiedu, E. (2002), "On the Determinants of Foreign Direct Investment to Developing Countries: Is Africa Different?", World Development 30, 107-19.

Baier, S. L, Bergstrand, J. H., and Feng, M. (2014), "Economic integration agreements and the margins of international trade," Journal of International Economics Vol. 93(2), 339-350.

Baier, S. L., Bergstrand, J. H., Egger, P., and McLaughlin, P. (2008), "Do economic integration agreements actually work? Issues in understanding the causes and consequences of the growth in regionalism", The World Economy, 31(4), 461-497. 
Baier, S.L. and J.H. Bergstrand (2004), "Economic determinants of free trade agreements." Journal of International Economics 61, 29-63.

Baier, S.L. and J.H. Bergstrand (2007), "Do Free Trade Agreements actually increase Members' International Trade?", Journal of International Economics, 71 (1), 72-95.

Baier, S.L. and J.H. Bergstrand (2009) "Estimating the effects of free trade agreements on international trade flows using matching econometrics." Journal of International Economics 77, 63-76.

Baldwin, J. R. and B. Yan (2010), "Death of Canadian Manufacturing Plants: Heterogeneous Responses to Changes in Tariffs and Real Exchange Rates," Economic Analysis Research Paper Series, Statistics Canada, Ottawa

Baltagi B. H., P. Egger, M. Pfaffermayr (2007a), "Estimating models of complex FDI: Are there third-country effects?", Journal of Econometrics 140, 260-281

Baltagi B. H., P. Egger, M. Pfaffermayr (2008), "Estimating regional trade agreement effects on FDI in an interdependent world", Journal of Econometrics, 145, 194-208

Barba Navaretti G. and A. J. Venables (2006), Multinational Firms in the World Economy, Princeton University Press.

Barthel, F., Busse, M. and E. Neumayer (2010), "The impact of double taxation treaties on foreign direct investment: evidence from large dyadic panel data", Contemporary Economic Policy, 28 (3), 366-377.

Belderbos R. (2003), “Antidumping and foreign divestment: Japanese electronics multinationals in the EU", Review of World Economics 139, p131-60

Belderbos R. and J. Zou (2006), "Foreign Investment, Divestment and Relocation by Japanese Electronics Firms in East Asia", Asian Economic Journal, Vol. 20 No. 1, 1-27.

Belderbos, R. (1997), “Antidumping and Tariff Jumping: Japanese Firms' FDI in the European Union and United States," Weltwirtschaftliches Archiv, 133(): 419-57

Bellak C. (2015), "Economic Impact of Investment Agreements", Vienna University of Economics and Business", Department of Economics, Working Paper No. 200,

Bellak C. and M. Leibrecht (2009), "Do low corporate income tax rates attract FDI? - Evidence from Central- and East European countries," Applied Economics 41, 2691-2703.

Bellak, C., M. Leibrecht and J. P. Damijan (2009), "Infrastructure Endowment and Corporate Income Taxes as Determinants of Foreign Direct Investment in Central and Eastern European Countries", World Economy 32 (2), 267-90.

Bellak, C., M. Leibrecht and A.Riedl (2008), "Labour costs and FDI flows into Central and Eastern European Countries: A survey of the literature and empirical evidence", Structural Change and Economic Dynamics, Vol 19: 1, 17-37.

Bénassy-Quéré, A., Coupet, M., and T. Mayer (2007), "Institutional Determinants of Foreign Direct Investment", World Economy, 30 (5), 764-782.

Bénassy-Quéré, A., Fontagné, L. and Lahrèche-Révil, A. (2001). Exchange rate strategies in the competition for attracting FDI, Journal of Japanese and International Economics 15, 178-198.

Benito, G. R. (2005), "Divestment and international business strategy", Journal of Economic Geography, 5(2), 235-251.

Benito, G. R.G (1997a), "Divestment of foreign production operations". Applied Economics, 29, 1365-1377.

Benito, G. R.G (1997b), ”Why are Foreign Subsidiaries Divested? A Conceptual Framework", in I. Björkman and M. Forsgren (eds.), The Nature of the International Firm, Copenhagen: Copenhagen Business School Press, 309-334.

Benito, G., and Welch, L. (1997), “De-internationalization”, Management International Review,37, 7-25.

Benito, G.R.G., (2005), "Divestment and international business strategy", Journal of Economic Geography, 5(2), 235-251.

DRIVERS OF DIVESTMENT DECISIONS OF MULTINATIONAL ENTERPRISES - A CROSS-COUNTRY FIRM-LEVEL PERSPECTIVE 
Berger, A., M. Busse, P. Nunnenkamp and M. Roy (2013), "Do trade and investment agreements lead to more FDI? Accounting for key provisions inside the black box", International Economics and Economic Policy, Vol 10, Issue 2, 247-275.

Bergstrand, J. H., and P. Egger. (2007) "A Knowledge-and-Physical-Capital Model of International Trade Flows, Foreign Direct Investment, and Multinational Enterprises," Journal of International Economics, 73(2): 278-308.

Bergstrand, J. H., and P. Egger. (2013), "What determines BITs?”, Journal of International Economics 90 (2013) 107-122.

Bernard A. B. and F. Sjöholm (2003), "Foreign Owners and Plant Survival”, NBER Working Paper Series, Working Paper 10039.

Bernard A. B. and J. B. Jensen (2007), "Firm Structure, Multinationals, and Manufacturing Plant Deaths", The Review of Economics and Statistics, Vol. LXXXIX, No 2.

Bernard A. B. and J. B. Jensen (2004), "Why Some Firms Export?”. The Review of Economics and Statistics, 86 (2): 561-569

Berry, H. (2010), "Why do firms divest?”, Organization Science, 21(2), 380-396.

Berry, H. (2013), "When Do Firms Divest Foreign Operations?”, Organization Science 24(1):246-261.

Biswas, R. (2002), "Determinants of Foreign Direct Investment," Review of Development Economics 6, 492-504.

Blake D. and C. Moschieri (2017), "Policy risk, strategic decisions and contagion effects: Firm-specific considerations", Strategic Management Journal. Vol. 38, Issue 3.

Bloomberg (2016), "Citigroup, HSBC Jettison Customers as Era of Global Empires Ends", www.bloomberg.com/graphics/2016-global-banks

Blomström, M. and A. Kokko (1998), "Multinational Corporations and Spillovers". Journal of Economic Surveys, Vol. 12, pp. 247-277.

Blonigen B. A., L. Fontagné, N. Sly, F. Toubal (2014): "Cherries for sale: The incidence and timing of cross-border M\&A", Journal of International Economics

Blonigen B. A., L. Oldenski and N. Sly (2014), "The Differential Effects of Bilateral Tax Treaties", American Economic Journal: Economic Policy, Vol. 6 No. 2, 1-18.

Blonigen B. A. and J. Piger (2011), Determinants of Foreign Direct Investment, NBER Working Papers, Working Paper 16704

Blonigen, B. A, (2005), "A Review of the Empirical Literature on FDI Determinants", NBER Working Paper No. 11299

Blonigen, B. A. and R. B. Davies (2004a), 'Do Bilateral Tax Treaties Promote Foreign Direct Investment?', in J. Hartigan (ed.), Handbook of International Trade Vol II: Economic and Legal Analysis of Trade Policy and Institutions (Boston, MA: Blackwell Publishers).

Blonigen, B. A. and R. B. Davies (2004b), 'The Effects of Bilateral Tax Treaties on U.S. FDI Activity', International Tax and Public Finance, 11, 601-22.

Blonigen, B. A. (2002) “Tariff-Jumping Antidumping Duties,” Journal of International Economics, Vol. 57(1): 31-50.

Blonigen, B. A., R. B. Davies, and K. Head (2003), "Estimating the Knowledge-capital Model of the Multinational Enterprise: Comment," American Economic Review 93:980-94.

Blonigen, B. and R. B. Davies (2005), "Do Bilateral Tax Treaties Promote Foreign Direct Investment?" In E. Kwan Choy and James Harrigan (eds.), Handbook of International Trade: Economic and Legal Analysis of Laws and Institutions. Blackwell.

Blonigen, B.A. and R.B. Davies (2004), The Effects of Bilateral Tax Treaties on U.S. FDI Activity, International Tax and Public Finance 11, 601-622.

Blyde, J., A. Graziano, C. Volpe Martincus (2015), Economic Integration Agreements and Production Fragmentation: Evidence on the Extensive Margin, Applied Economics Letters Vol 22, Issue 10. 
Boddewyn, J. J. (1983a), "Foreign and domestic divestment and investment decisions: Like or unlike?", Journal of International Business Studies 14, 23-35.

Boddewyn, J. J. (1983b), "Foreign Direct Divestment Theory: Is It the Reverse of FDI Theory?", Weltwirtschaftliches Archiv, 119 (2), pp.345-355.

Botta, E. and T. Koźluk (2014), "Measuring environmental policy stringency in OECD countries: A composite index approach", OECD Economics Department Working Papers, No. 1177, OECD Publishing.

Brainard, S. L. (1997), "An Empirical Assessment of the Proximity-concentration Trade-off between Multinational Sales and Trade," American Economic Review 87, 520-44.

Brauer, M. (2006), "What have we acquired and what should we acquire in divestiture research? A review and research agenda", Journal of Management, 32(6), 751-785.

Brzozowski, M. (2006). "Exchange rate variability and foreign direct investment consequences of EMU enlargement", Eastern European Economics 44, 5-24.

Buckley, F. H. (1991), “The divestiture decision”, Journal of Corporation Law, 32, 805-859.

Capron, L, W. Mitchell and A. Swaminathan (2001), "Asset divestiture following horizontal acquisitions: a dynamic view”, Strategic Management Journal 22(9), 817-844.

Carr, David L., J. R. Markusen, and K. E. Maskus (2001), "Estimating the Knowledge-capital model of the Multinational Enterprise," American Economic Review 91, 693-708.

Caves, R. E. (2007), Multinational Enterprise and Economic Analysis, New York, NY: Cambridge University Press

Chen, M. X. and C. G. Bao (2018), "Foreign Rivals are Coming to Town: Responding to the Threat of Foreign Multinational Entry", American Economic Journal: Applied Economics 10(4), 2018, 120-57.

Cheng L.K. and Y. K. Kwan (2000), "What are the determinants of the location of foreign direct investment? The Chinese experience", Journal of International Economics, Vol. 51, Issue 2, 379-400.

CNN (2018), "The dismantling of GE continues: It is selling yet another business", www.edition.cnn.com/2018/11/06/business/general-electric-current-salelighting/index.html

CNN (2017), "GM is selling its European business in \$2.3 billion deal", www.money.cnn.com/2017/03/06/investing/general-motors-psa-opel-vauxhallpeugeot-citroen-deal

Corcoran A. and R. Gillanders (2015), "Foreign direct investment and the ease of doing business", Review of World Economics, Volume 151, Issue 1, 103-126

Crespo, N. and Fontoura, M.P. (2007), "Determinant factors of FDI spillovers-what do we really know?", World Development 35 (3), 410-425.

Criscuolo, C., Martin, R. (2009), Multinationals and U.S. productivity leadership: evidence from Great Britain, Review of Economics and Statistics, 91 (2), 263-281.

Crozet, M., T. Mayer and J.-L. Mucchielli (2004), "How do firms agglomerate? A study of FDI in France," Regional Science and Urban Economics, Elsevier, Vol. 34(1), 27-54.

Daude, C. and E. Stein (2007), "The quality of institutions and foreign direct investment", Economics \& Politics, 19: 317-44

De Backer, K. et al. (2016), "Reshoring: Myth or Reality?”, OECD Science, Technology and Industry Policy Papers, No. 27, OECD Publishing, Paris. http://dx.doi.org/10.1787/5jm56frbm38s-en

De Backer, K. et al. (2016), “Reshoring: Myth or Reality?”, OECD Science, Technology and Industry Policy Papers, No. 27, OECD Publishing, Paris. http://dx.doi.org/10.1787/5jm56frbm38s-en

de Mooij, R. A. and S. Ederveen (2003), "Taxation and foreign direct investment: A synthesis of empirical research", International Tax and Public Finance, 10, 673-693. 
Deighton-Smith, R., A. Erbacci and C. Kauffmann (2016), "Promoting inclusive growth through better regulation: The role of regulatory impact assessment", OECD Regulatory Policy Working Papers, No. 3, OECD Publishing, Paris, https://doi.org/10.1787/5jm3tqwqp1 vj-en.

Dewitt, G., H. Görg and C. Montagna (2003), "Should I Stay or Should I Go? A Note on Employment Protection, Domestic Anchorage, and FDI," mimeo, University of Nottingham.

Devereux, M. P., and H. Freeman (1995), "The impact of tax on foreign direct investment: Empirical evidence and the implications for tax integration schemes", International Tax and Public Finance, 2, 85-106.

Di Giovanni, J. (2005) "What Drives Capital Flows? The Case of Cross-Border M\&A Activity and Financial Deepening." Journal of International Economics 65 (1), 127-49.

Disdier, A-C., and T. Mayer (2007), "Je t'aime, moi non plus: Bilateral Opinions and International Trade", European Journal of Political Economy 23(4), 1140-1159

Djankov, S. and B. Hoekman, (2000), "Foreign investment and productivity growth in Czech enterprises", World Bank Economic Review 14 (1), 49-64.

Driffield, N. and S. Girma (2003), "Regional Foreign Direct Investment and Wage Spillovers: Plant Level Evidence from the Electronics Industry", Oxford Bulletin of Economics and Statistics, Vol. 65, Iss. 4, 453-474.

Dunning, J. H. (2000), "The Eclectic Paradigm as an Envelope for Economic and Business Theories of MNE Activity," International Business Review, 9(2), 163-190.

Dür, A., Baccini, L., Manfred, E., (2014). "The design of international trade agreements: Introducing a new database", Review of International Organizations 9 (3), p. 353-375, University Press, Cambridge, 22-51.

Egger P. and D. M. Radulescu (2011), "Labor Taxation and Foreign Direct Investment", The Scandinavian Journal of Economics 113: 3, 603-636.

Egger P. and V. Merlo (2012), "BITs Bite: An Anatomy of the Impact of Bilateral Investment Treaties on Multinational Firms", Scandinavian Journal of Economics 114(4), 1240-66,

Egger, P., and Pfaffermayr, M. (2004), "The Impact of Bilateral Investment Treaties on Foreign Direct Investment”, Journal of Comparative Economics, 32(4), 788-804. doi: https://doi.org/10.1016/j.jce.2004.07.001.E

Egger P., S. Loretz, M. Pfaffermayr and H. Winner (2009), "Bilateral effective tax rates and foreign direct investment", International Tax Public Finance 16: 822-849

Egger, P., M. Larch, M. Pfaffermayr, and H. Winner (2006), "The Impact of Endogenous Tax Treaties on Foreign Direct Investment: Theory and Evidence", Canadian Journal of Economics, 39(3), pp. 901-931.

Eren, M. and H. Zhuang (2015), "Mergers and acquisitions versus greenfield investment, absorptive capacity, and economic growth: Evidence from 12 new member states of the European Union", Eastern European Economics, 53(2), 99-123.

Ernst \& Young (2019b), "Divestment intentions remain high on the UK corporate agenda", www.ey.com/en_gl/divestment-study/2019/united-kingdom

Ernst \& Young (2019a), Global Corporate Divestment Study, www.ey.com/en_gl/divestment-study

Financial Times (2018), "Nestlé bows to investor and sector pressures with strategic shift", www.ft.com/content/bfa28d4e-a286-11e7-9e4f-7f5e6a7c98a2

Financial Times (2017), "RBS fire sales meant UK taxpayers lost out on potential £15bn", www.ft.com/content/da04a194-61a5-11e7-8814-0ac7eb84e5f1

Fluck, Z. and A. W. Lynch (1991), "Why do firm merge and then divest? A theory of financial synergy", Journal of Business, 72(3): 319-346.

Forbes (2017), "One Price Of Uncertainty: Corporates Selling Off Non-Core European Assets",www.forbes.com/sites/davidschrieberg1/2017/06/01/one-price-of-uncertaintycorporates-selling-off-non-core-european-assets 
Gal, P. (2013), "Measuring Total Factor Productivity at the Firm Level using OECDORBIS”, OECD Economics Department Working Papers No. 1049, OECD, Paris.

Garsous, G. and T. Kozluk (2017), "Foreign Direct Investment and the Pollution Haven Hypothesis: Evidence from Listed Firms", OECD Economics Department Working Papers, No. 1379, OECD Publishing, Paris, https://doi.org/10.1787/1e8c0031-en.

Girma, S., D. Greenaway and K. Wakelin (2001), "Who benefits from foreign direct investment in the UK", Scottish Journal of Political Economy, 48, 119-133.

Girma, S. and H. Görg (2007), "Multinationals' productivity advantage: scale or technology?", Economic Inquiry 45 (2), 350-362.

Gómez-Plana, A. G. and M. C. Latorre (2013), "When Multinationals Leaves: A CGE Analysis of the Impact of Divestments", Economics Discussion Papers, No 2013-45, Kiel Institute for the World Economy.

Goldberger, A. S. (1991), A Course in Econometrics, Cambridge, MA: Harvard University Press.

Gordon, K. and J. Pohl (2015), "Investment Treaties over Time - Treaty Practice and Interpretation in a Changing World", OECD Working Papers on International Investment, 2015/02, OECD Publishing. http://dx.doi.org/10.1787/5js7rhd8sq7h-en

Görg H. and E. Strobl (2003), “Footloose' Multinationals?”, The Manchester School, 71: 1, 14636786

Görg, H. (2005). "Fancy a Stay at the "Hotel California"? Foreign Direct Investment, Investment Incentives, and Exit Costs." Kyklos, Vol. 58 - 2005 - No. 4, 519-535.

Görg H. and E. Strobl (2001), Multinational Companies and Productivity Spillovers: A Metaanalysis. Economic Journal, 111, F723-F739.

Görg, H. and E. Strobl (2005), "Spillovers from Foreign Firms through Worker Mobility: An Empirical Investigation", Scandinavian Journal of Economics, Vol. 107, No. 4, 693-709.

Görg, H., and D. Greenway (2004), "Much ado about nothing? Do domestic firms really benefit from foreign direct investment?", The World Bank Research Observer, 19(2), 171-197.

Grubert, H. and J. Mutti (1991), "Taxes, Tariffs and Transfer Pricing in Multinational Corporate Decision Making," Review of Economics and Statistics, 73(2): 285-293

Guadalupe, M., O. Kuzmina, and C. Thomas (2012). "Innovation and Foreign Ownership." American Economic Review, 102(7), 3594-3627.

Hallward-Driemeier, M. (2003), Do Bilateral Investment Treaties Attract FDI? Only a Bit ... And They Could Bite, Working Paper No. 3121, The World Bank, Washington

Haddad, M. and Harrison, A. (1993), "Are there Positive Spillovers from Foreign Direct Investment? Evidence from Panel Data for Morocco", Journal of Development Economics 42, 51-74.

Harding T. and B. Javorcik (2012), "Investment Promotion and FDI Inflows: Quality Matters," Economics Series Working Papers 612, University of Oxford.

Harding T. and B. S. Javorcik (2011), "Roll Out the Red Carpet and They Will Come: Investment Promotion and FDI Inflows," Economic Journal, Royal Economic Society, 121(557), 1445-76.

Harrison, A. and A. Rodriguez-Clare (2010), "Trade, Foreign Investment, and Industrial Policy." In Rodrik, D., Rosenzweig, M.R. (Eds.), Handbook of Development Economics, Amsterdam: Elsevier, 4039-4214.

Haskel, J. E., Pereira, S. C., and Slaughter, M. J. (2007), "Does Inward Foreign Direct Investment Boost the Productivity of Domestic Firms?", The Review of Economics and Statistics, 89: 3, 482-496

Havránek and Iršová (2013), "Determinants of Horizontal Spillovers from FDI: Evidence from a Large Meta-Analysis", The World Development, Vol. 42, 1-15

Havránek, T., Iršová, Z. (2010), "Which Foreigners Are Worth Wooing? A Meta-Analysis of Vertical Spillovers from FDI", IES Working Paper 16/2010 
Head, K. and Ries, J. (2008), "FDI as an outcome of the market for corporate control: theory and evidence", Journal of International Economics, 74 (1), 2-20.

Helpman, E. (2006), "Trade, FDI, and the Organization of Firms," Journal of Economic Literature, 44(3): 589-630.

Helpman, E., M. J. Melitz, S. R. Yeaple (2004), "Exports versus FDI with Heterogeneous Firms", American Economic Review 94, 300-16.

Jagersma, P.K. and D. M. van Gorp (2003), International Divestments: An Empirical Perspective, Journal of General Management, 29(1)47-67.

Javorcik, B. S. (2004a), "Does Foreign Direct Investment Increase the Productivity of Domestic Firms? In Search of Spillovers through Backward Linkages," American Economic Review, 94(3): 605-627.

Javorcik, B. S. (2004b), "The composition of foreign direct investment and protection of intellectual property rights: Evidence from transition economies", European Economic Review, 48, 39-62.

Javorcik, B. S. and M. Spartareanu (2005), "Do Foreign Investors Care about Labor Market Regulations?", Review of World Economics 141 (3), 375-403.

Javorcik, B. S. and M. Spartareanu (2008), "To share or not to share: Does local participation matter for spillovers from foreign direct investment?," Journal of Development Economics, Vol. 85(12), 194-217.

Javorcik, B. S. and S. J. Wei (2009), "Corruption and cross-border investment in emerging markets: Firm-level evidence," Journal of International Money and Finance, 28(4), 605-624.

Javorcik, B. S. and S. Poelhekke (2017), "Former Foreign Affiliates: Cast Out and Outperformed?", Journal of the European Economic Association, Vol 15, Issue 3, 501-539.

Javorcik, B. S., K. Saggi and M. Spartareanu (2004), "Does it matter where you come from? Vertical spillovers from foreign direct investment and the nationality of investors," The World Bank Policy Research Working Paper Series 3449.

Jayasuriya D. (2011), "Improvements in the World Bank's Ease of Doing Business Rankings: Do They Translate into Greater Foreign Direct Investment Inflows?”, World Bank Policy Research Working Paper No. 5787

Kalemli-Ozcan S., B. Sorensen, C. Villegas-Sanchez, V. Volosovych, S. Yesiltas (2015), "How to Construct Nationally Representative Firm Level data from the ORBIS Global Database", NBER Working Paper No. 2155

Keller, W. and S. R. Yeaple (2009), "Multinational Enterprises, International Trade, and Productivity Growth: Firm-Level Evidence from the United States," The Review of Economics and Statistics, Vol. 91(4), 821-831.

Kinda, T. (2010), "Investment Climate and FDI in Developing Countries: Firm-Level Evidence," World Development, Elsevier, 38(4), 498-513.

Kogut, B. and N. Kulatilaka (1994). "Operating Flexibility, Global Manufacturing, and the Option Value of a Multinational Network.” Management Science, 40, 123-139.

Kogut, B. and S. J. Chang (1991,) "Technological Capabilities and Japanese Foreign Direct Investment in the United States," Review of Economics and Statistics, 73(3): 401-13.

Kohl, T. (2014) "Do we really know that trade agreements increase trade?", Review of World Economics, 150(3), 443-469.

Kohl, T., Brakman, S., and Garretsen, J. H. (2016), "Do trade agreements stimulate international trade differently? Evidence from 296 trade agreements", The World Economy, 39(1), 97-131.

Koźluk, T. and C. Timiliotis (2016), "Do environmental policies affect global value chains?: A new perspective on the pollution haven hypothesis", OECD Economics Department Working Papers, No. 1282, OECD Publishing, Paris, https://doi.org/10.1787/5jm2hh7nf3wd-en. 
Lee D, and R. Madhavan (2010), "Divestiture and Firm Performance: A Meta-Analysis", Journal of Management, Vol. 36, No. 6, pp. 1345-1371.

Lancaster, T. (2000), “The incidental parameter problem since 1948”, Journal of Econometrics 95, 391-413.

Lipsey, R. E., and Sjoholm, F. (2004), "Foreign direct investment, education and wages in Indonesian manufacturing", Journal of Development Economics, 73(1), 415-422.

Lundan S. M. (2006), "Reinvested earnings as a component of FDI: an analytical review of the determinants of reinvestment", Transnational Corporations, Vol. 15, No. 3.

Markides, C.C., (1992), "Consequences of corporate refocusing: ex ante evidence". Academy of Management Journal 35 (2), 398-412.

Markides, C.C., (1995), "Diversification, restructuring and economic performance", Strategic Management Journal 16, 101-118.

Markusen, J. R., Multinational Firms and the Theory of International Trade, Cambridge, MA: The MIT Press (2002).

Martins, P. S. and L. A. Esteves (2008), "Foreign Ownership, Employment and Wages in Brazil: Evidence from Acquisitions, Divestments and Job Movers," IZA Discussion Papers 3542, Institute for the Study of Labor (IZA).

Mistura, F. and C. Roulet (2019), "The determinants of Foreign Direct Investment: Do statutory restrictions matter?", OECD Working Papers on International Investment, No. 2019/01, OECD Publishing, Paris, https://doi.org/10.1787/641507ce-en

Moulton, B. R. (1990), "An Illustration of a Pitfall in Estimating the Effects of Aggregate Variables on Micro Units", The Review of Economics and Statistics, Vol. 72, No. 2, 334-338.

Nicoletti, G., S. Golub, D. Hajkova, D. Mirza and K-Y. Yoo (2003), "The Influence of Policies on Trade and FDI", OECD Economic Studies, No. 36, OECD Publishing, Paris.

Neary, J.P., (2007), "Cross-border mergers as instruments of comparative advantage”, Review of Economic Studies 74 (4), 1229-1257.

Neyman, J., Scott, E.L. (1948), "Consistent estimation from partially consistent observations", Econometrica 16, 1-32.

Nocke, V. and Yeaple, S.R. (2007), "Cross-border mergers and acquisitions versus greenfield foreign direct investment: the role of firm heterogeneity", Journal of International Economics. 72 (2), 336-365.

Nocke, V. and Yeaple, S.R. (2008), “An assignment theory of foreign direct investment”, Review of Economic Studies, 75 (2), 529-557.

Nokia (2019), Divestments and Acquisitions, www.nokia.com/about-us/investors/acquisitionsdivestments

Noorbakhsh, F., Paloni, A. and Youssef, A. (2001). "Human Capital and FDI Inflows to countries: New Empirical Evidence”, World Development, 29(9), 1593-1610.

Noorbakhsh, F., Paloni, A., and Youssef, A. (2001). Human capital and FDI inflows to developing countries: New empirical evidence. World Development, 29(9), 1593-1610.

Norbäck, P.-J., A. Tekin-Koru \& A. Waldkirchet al. (2015), "Multinational Firms and Plant Divestiture", Review of International Economics, 23(5), 811-845

OECD (2008a). Benchmark Definition of Foreign Direct Investment, Fourth Edition, OECD Publishing, Paris.

OECD (2008b), "The Impact of Foreign Direct Investment on Wages and Working Conditions", OECD-ILO Conference on Corporate Social Responsibility.

OECD (2008c), Government Strategies to Attract R\&D-Intensive FDI, OECD Global Forum on International Investment, www.oecd.org/investment/globalforum/40310856.pdf.

OECD (2013), "Protecting jobs, enhancing flexibility: A new look at employment protection legislation", in OECD Employment Outlook 2013, OECD Publishing. https://doi.org/10.1787/empl_outlook-2013-6-en 
OECD (2015a), Policy Framework for Investment, 2015 Edition, OECD Publishing, Paris. http://dx.doi.org/10.1787/9789264208667-en

OECD (2015b), "Divestment and Stranded Assets in the Low-carbon Transition", Background paper for the 32nd Round Table on Sustainable Development, OECD Publishing, Paris.

OECD (2018a), OECD Foreign Direct Investment Statistics database, www.oecd.org/investment/statistics.htm

OECD (2018b), Mapping of Investment Promotion Agencies in OECD countries, OECD Publishing, Paris.

OECD (2018c), Compendium of Productivity Indicators 2018, OECD Publishing, www.oecdilibrary.org/industry-and-services/oecd-compendium-of-productivity-indicators_

OECD (forthcoming), Data preparation for use on international investment analysis using ORBIS: a new empirical firm-level database, OECD Publishing, Paris.

OECD-UNCTAD (2018), $19^{\text {th }}$ Report on G20 Investment Measures, November 2017.

Orefice, G. and Rocha, N. (2014) Deep integration and production networks: an empirical analysis, The World Economy, 37, 106-36.

Papandropoulos P. and A. Tajana, (2006) 'The Merger Remedies Study: In Divestiture We Trust?", 27(8) European Competition Law Review 443-54.

Pinto Ribeiro, S., S. Menghinello and K. De Backer (2010), “The OECD ORBIS Database: Responding to the need for Firm-Level Micro-Data in the OECD”, OECD Statistics Working Paper Series, OECD: Paris

Pohl, J. (2018), "Societal benefits and costs of International Investment Agreements: A critical review of aspects and available empirical evidence", OECD Working Papers on International Investment, OECD Publishing, Paris. http://dx.doi.org/10.1787/e5f85c3d-en

Procher, V. D. and D. Engel (2017), The investment-divestment relationship: Resource shifts and intersubsidiary competition within MNEs, International Business Review

Reuters (2013), "Daimler exits EADS with \$2.9 billion placement" www.reuters.com/article/usdaimler-eads/daimler-exits-eads-with-2-9-billion-placementidUSBRE93G08K20130417

Reuters (2013), "Eastman Kodak to sell document imaging business assets", www.reuters.com/article/us-eastman-kodak-divestment/eastman-kodak-to-selldocument-imaging-business-assets-idUSBRE93E0NK20130415

Ramondo N. (2009), "Foreign Plants and Industry Productivity: Evidence from Chile," Scandinavian Journal of Economics, Vol. 111(4), 789-809.

Rugman, A. M. (1980), "Internalization as a General Theory of Foreign Direct Investment: A Re-Appraisal of the Literature", Weltwirtschaftliches Archiv, Vol. 116, 365-379.

Sauvant S. K. and L. E. Sachs (2009), The Effect of Treaties on Foreign Direct Investment: Bilateral Investment Treaties, Double Taxation Treaties, and Investment Flows . Oxford: Oxford University Press.

Sembenelli A. and D. Vannoni (2000), "Why Do Established Firms Enter Some Industries and Exit Others? Empirical Evidence on Italian Business Groups," Review of Industrial Organization, Springer; Vol. 17(4), 441-456.

Sorbe, S. and Å. Johansson (2017), "International tax planning and fixed investment", OECD Economics Department Working Papers, No. 1361, OECD Publishing, Paris.

Soule S. A., A. Swaminathan and L. Tihany (2014), "The Diffusion of Foreign Divestment From Burma", Strategic Management Journal, 35: 1032-1052

Swenson D. L. and H. Chen (2014), "Multinational Exposure and the Quality of New Chinese Exports," Oxford Bulletin of Economics and Statistics, Department of Economics, University of Oxford, Vol. 76(1), 41-66.

Swenson, D. L. (2008), "Multinationals and the Creation of Chinese Trade Linkages," Canadian", Journal of Economics, Vol. 41 (2), 596-618. 
Tan Q. and C. M.P. Sousa, (2015) "Leveraging marketing capabilities into competitive advantage and export performance", International Marketing Review, 32(1), 78-102.

Tobin, J. and Rose-Ackerman, S. (2005), Foreign Direct Investment and the Business Environment in Developing Countries: the Impact of Bilateral Investment Treaties, Economics and Public Policy Research Paper No. 293, Yale Law School.

UNCTAD, (2001-2018), World Investment Report 2001-2018

Van Beveren, I. (2007), "Footloose Multinationals in Belgium?", Review of World Economics (Weltwirtschaftliches Archiv), Vol. 143, issue 3, 483-507

WEF (2015-16), Global Competitiveness Index 2007-16.

Wei, S. J. (1997), "Why Is Corruption So Much More Taxing than Tax Arbitrariness Kills", NBER Working Paper No. 6255.

Wei, S. J. (2000), "How taxing is corruption on internal investors?", The Review of Economics and Statistics, 82(1), 1-11.

Wheeler, D. and Mody, A. (1992), "International Investment Location Decisions: The Case of U.S. Firms", Journal of International Economics, 33, 57-76

Yeaple, S.R. (2003), "The complex integration strategies of multinational firms and cross-country dependencies in the structure of foreign direct investment", Journal of International Economics 60, 293-314. 


\section{Annex A. Data}

The data used in this paper come from multiple sources. First, firm-level data comes from Bureau van Dijk (ORBIS). The ORBIS database offers one of the richest sources of firmlevel data with ownership and financial information available for a number of countries over time, and has been used in studies of FDI and MNE behaviour (e.g. Alfaro and Chen, 2018; Chen and Bao, 2018; Kalemli-Ozcan et al., 2015; Fons-Rosen et al., 2013).

After a thorough data-construction and cleaning exercise, a panel dataset has been created, containing financial and ownership information for 770,669 affiliates from 41 selected OECD and G20 countries as well as their parents located in 164 different countries. Both financial and legal information is available for years 2007-2014, allowing the tracing of ownership changes and financial performance of the affiliates over time. The database also includes information on these affiliates' parents, located in 164 different countries, including their financial information (at a consolidated level), legal information and other data on their economic groups that allows us to construct control variables (e.g. total number of affiliates, total number of 4-digit NAICS sectors, total number of countries in which the MNE operates). A forthcoming methodological paper describes in detail the data construction and cleaning process (OECD, forthcoming).

About 62000 of affiliate firms in the sample were foreign-owned in 2007. Over 13000 of those foreign-owned firms (i.e. 22\%) were divested at least once by their foreign parent (i.e. majority control was transferred from a foreign to a domestic global ultimate owner) between 2007 and 2014. Table A1 provides an overview of countries included in the analysis and Figures A1 and A2 provide information on the number of firms by host and home country. In some regressions, the sample is extended to 146 countries for which ownership information is available in ORBIS even though it is not possible to use financial data for those firms due to limited data coverage (see Ribeiro et al., 2010 and KalemliOzcan et al., 2015).

Data on host country policies come from many different sources, including the OECD, World Bank, CEPII, World Economic Forum, Transparency International. Data on regional trade agreements (RTAs) come from Baier et al. (2014) and Kohl et al. (2016), on international investment agreements (IIAs) from the OECD Database on International Investment Agreements, and on double taxation agreements (DTTs) from the Exchange of Tax Information Portal of the Global Forum on Transparency and the OECD. All sources and definitions are provided in Table 3 of this paper. 
Table A.1. List of countries included in the database.

\begin{tabular}{|c|c|}
\hline Number & Country \\
\hline 1 & Argentina \\
\hline 2 & Austria \\
\hline 3 & Australia \\
\hline 4 & Belgium \\
\hline 5 & Bulgaria \\
\hline 6 & Brazil \\
\hline 7 & Switzerland \\
\hline 8 & Chile \\
\hline 9 & China \\
\hline 10 & Czech Republic \\
\hline 11 & Germany \\
\hline 12 & Denmark \\
\hline 13 & Spain \\
\hline 14 & Finland \\
\hline 15 & France \\
\hline 16 & United Kingdom \\
\hline 17 & Greece \\
\hline 18 & Croatia \\
\hline 19 & Hungary \\
\hline 20 & Indonesia \\
\hline 21 & Ireland \\
\hline 22 & India \\
\hline 23 & Iceland \\
\hline 24 & Italy \\
\hline 25 & Japan \\
\hline 26 & Korea \\
\hline 27 & Lithuania \\
\hline 28 & Luxembourg \\
\hline 29 & Latvia \\
\hline 30 & Malta \\
\hline 31 & Netherlands \\
\hline 32 & Norway \\
\hline 33 & New Zealand \\
\hline 34 & Poland \\
\hline 35 & Portugal \\
\hline 36 & Romania \\
\hline 37 & Russia \\
\hline 38 & Sweden \\
\hline 39 & Slovenia \\
\hline 40 & Slovakia \\
\hline 41 & Turkey \\
\hline
\end{tabular}

Source: Authors using ORBIS (C) data. 
Figure A.1. Number of firms in the sample, by country, 2008-2014.

\section{Panel A. Host country of the affiliate firm}

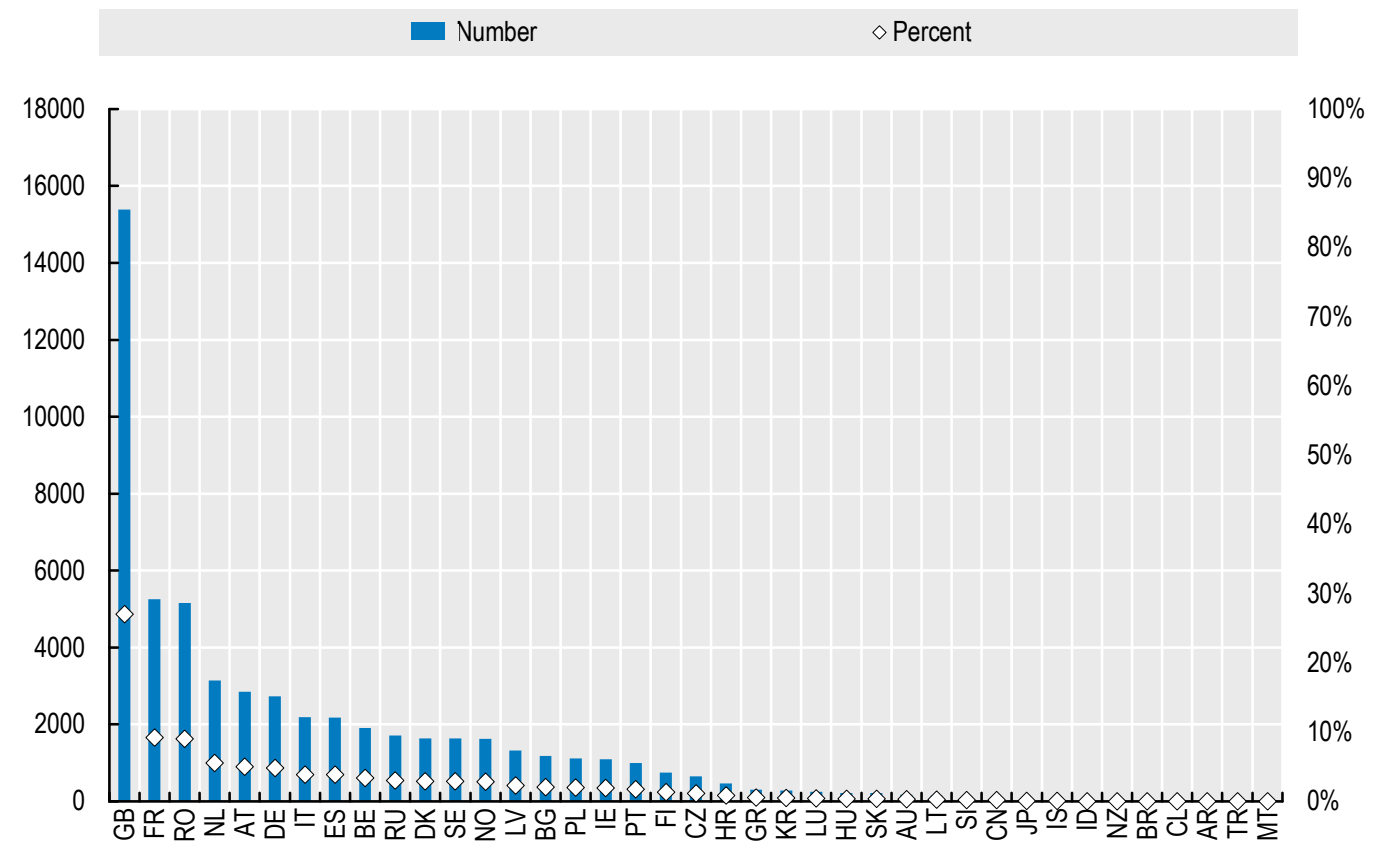

Panel B. Home country of the parent firm*

Number $\quad$ Percent

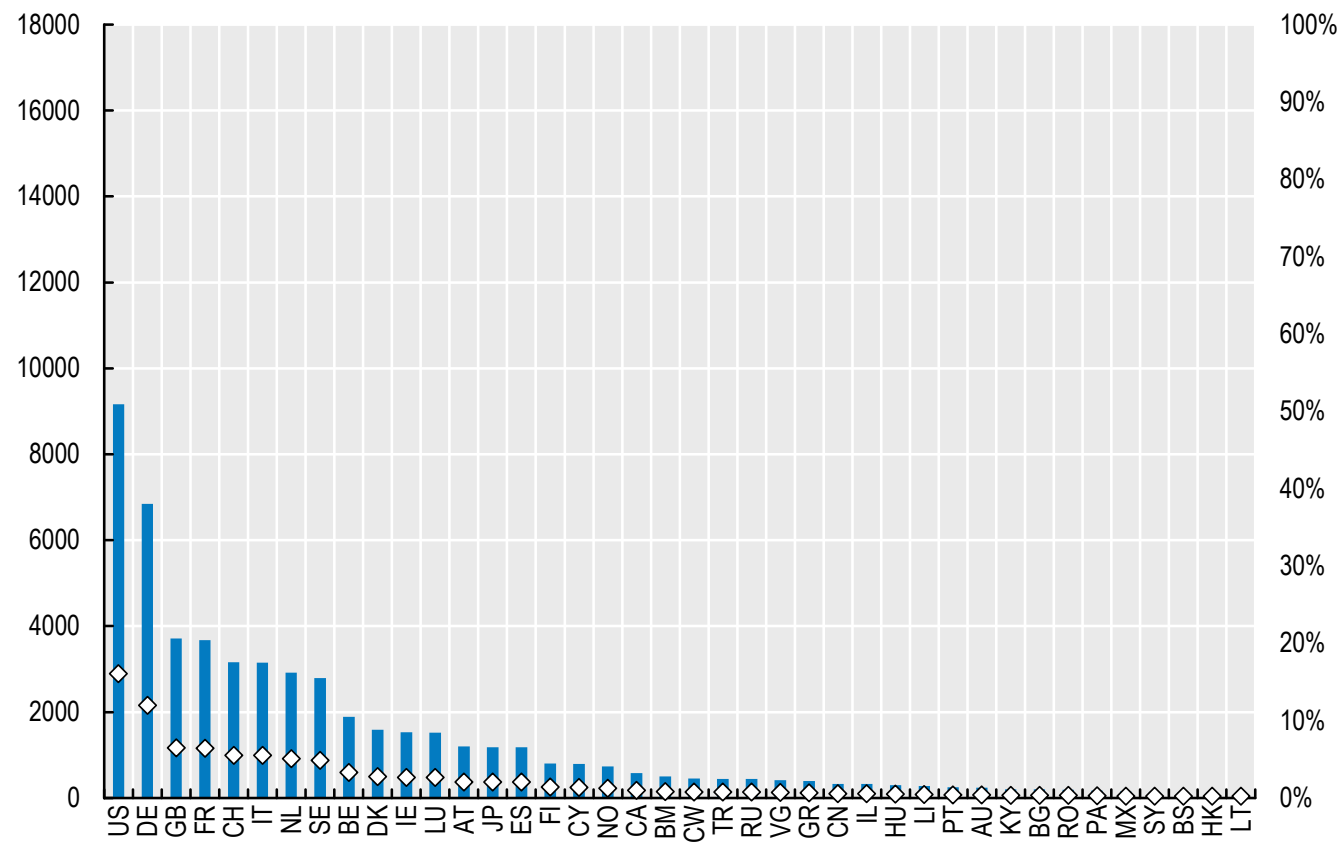

Note: *The figure shows top 40 home countries with the largest number of affiliates in the dataset. Source: Authors calculations using ORBIS (C) data. 
Table A.2. Summary statistics

\begin{tabular}{|c|c|c|c|c|c|c|}
\hline Variables & $\begin{array}{l}\text { Number of } \\
\text { observations }\end{array}$ & Mean & $\begin{array}{l}\text { Standard } \\
\text { deviation }\end{array}$ & Min & Median & $\operatorname{Max}$ \\
\hline Divestment & 423057 & 0.04 & 0.19 & 0.00 & 0.00 & 1.00 \\
\hline Log GDP t-1 & 485498 & 27.74 & 1.43 & 22.47 & 28.08 & 36.90 \\
\hline Log GDP pc t-1 & 485498 & 10.62 & 1.1 & 9.05 & 10.30 & 17.54 \\
\hline Log Real Exchange Rate t-1 & 480647 & 4.63 & 0.06 & 4.32 & 4.61 & 5.01 \\
\hline Log Real Exchange Rate Variability t-1 & 353751 & 0.89 & 0.77 & -1.24 & 0.88 & 3.31 \\
\hline Log Trade-to-GDP & 485498 & 3.68 & 0.39 & 2.43 & 3.53 & 5.11 \\
\hline Log Unit Labour Costs (ULC) & 468656 & 4.64 & 0.07 & 4.35 & 4.65 & 4.92 \\
\hline Log Tax rate t-1 & 485494 & 3.75 & 0.27 & 2.91 & 3.72 & 4.92 \\
\hline Log Applied Trade Tariff Rate t-1 & 484771 & 0.27 & 0.39 & -0.89 & 0.23 & 2.31 \\
\hline Log Time to Trade t-1 & 485494 & 2.27 & 0.33 & 1.70 & 2.20 & 3.11 \\
\hline Log Quality of Overall Infrastructure t-1 & 485498 & 1.61 & 0.27 & 0.84 & 1.68 & 1.89 \\
\hline Log Corruption (TI) t-1 & 485490 & 1.87 & 0.32 & 0.74 & 2.01 & 2.25 \\
\hline Log Political Stability t-1 & 455708 & -0.66 & 0.77 & -4.42 & -0.61 & 0.41 \\
\hline Log Environmental Policy Stringency t-1 & 371977 & 1.02 & 0.36 & -0.98 & 1.10 & 1.42 \\
\hline Log Education t-1 & 470133 & 4.39 & 0.05 & 3.84 & 4.39 & 4.51 \\
\hline Log Labour Market Efficiency t-1 & 485498 & 1.54 & 0.11 & 1.09 & 1.55 & 1.72 \\
\hline Log Inflation t-1 & 463388 & 0.79 & 0.86 & -7.39 & 0.90 & 2.74 \\
\hline Distance t-1 & 478947 & 7.09 & 1.25 & 2.95 & 7.02 & 9.88 \\
\hline IIAs t-1 & 485498 & 0.74 & 0.44 & 0.00 & 1.00 & 1.00 \\
\hline DTTs t-1 & 485498 & 0.86 & 0.35 & 0.00 & 1.00 & 1.00 \\
\hline RTAs t-1 & 485498 & 0.71 & 0.46 & 0.00 & 1.00 & 1.00 \\
\hline Log Affiliate's Fixed Assets t-1 & 393835 & 13.52 & 3.41 & 0.00 & 13.61 & 25.69 \\
\hline Log Affiliate's Liquidity Ratio t-1 & 419204 & 0.51 & 1.77 & - & 0.40 & 18.73 \\
\hline Log Affiliate's RoA t-1 & 211012 & -2.41 & 1.19 & - & -2.24 & 15.58 \\
\hline $\begin{array}{l}\text { Other Affiliates in the Same Host Country } \\
\text { Dummy t-1 }\end{array}$ & 485498 & 0.67 & 0.47 & 0.00 & 1.00 & 1.00 \\
\hline $\begin{array}{l}\text { Same Sector as Parent's Core Sector } \\
\text { Dummy t-1 }\end{array}$ & 288449 & 0.15 & 0.36 & 0.00 & 0.00 & 1.00 \\
\hline Log Economic Group's Total Assets t-1 & 197803 & 21.79 & 2.46 & 8.17 & 22.06 & 28.41 \\
\hline Log Economic Group's Liquidity Ratio t-1 & 197516 & 0.4 & 0.59 & -8.95 & 0.36 & 12.61 \\
\hline Log Economic Group's RoA t-1 & 178861 & -2.35 & 0.74 & 11.04 & -2.25 & 2.75 \\
\hline Log Economic Group's Solvency Ratio t-1 & 193125 & -1.06 & 0.6 & 10.45 & -0.96 & 5.78 \\
\hline $\begin{array}{l}\text { Economic Group's No. of Sectors } \\
\text { Covered t-1 }\end{array}$ & 483336 & 1.27 & 0.87 & 0.00 & 1.39 & 2.94 \\
\hline $\begin{array}{l}\text { Log Economic Group's } \\
\text { Internationalisation Level t-1 }\end{array}$ & 463834 & -0.49 & 0.49 & -6.80 & -0.37 & 0.00 \\
\hline $\begin{array}{l}\text { Log Economic Group's No. of Countries } \\
\text { Covered t-1 }\end{array}$ & 485498 & 2.09 & 1.36 & 0.00 & 1.95 & 4.84 \\
\hline
\end{tabular}

Source: Authors calculations using ORBIS @ data. 


\section{Annex B. Effect of foreign divestments on firm performance}

\section{Empirical estimation}

In the baseline estimation, the following model is used to explore the relationship between foreign divestments and firm performance:

$$
\ln X_{f s c t}=\alpha D_{f s c t}+\lambda_{s c t}+\varepsilon_{f s c t}
$$

where $f$ denotes affiliate firm, $s$ stands for sector, $c$ corresponds to the host country, and $t$ indexes year; $X=\{$ Sales, Employees, Value Added, Turnover per Employee, Value Added per Employee, ROA, Liquidity Ratio $\} ; D$ is a binary indicator that takes the value of one if the affiliate firm $f$ operating in sector $s$ in host country $c$ is divested by a foreign parent firm; $\lambda_{s c t}$ is a set of sector-host country-year fixed effects that accounts for systematic time-varying differences across host countries and sectors such as size, level of development, sectoral comparative advantages, and country-specific sectoral policies; and $\varepsilon$ is the error term.

The comparison group for the baseline regressions are firms that were foreign-owned at the beginning of the sample period, 2007, and have never been divested. This shows the effect of foreign divestment on the performance of firms without the conflating effects of business cycle fluctuations, sectoral dynamics, etc. To identify the effect of a nationality change on firm performance beyond the sheer effect of a change of an owner, a sale of a foreign-owned affiliate to another ultimate foreign owner is also explicitly accounted for.

Several alternative specifications are tested and robustness checks performed. For example, in one specification the comparison group is changed to compare performance of divested foreign-owned firms to those that remained domestic-owned firms throughout the whole period; and, in another, additional controls for several years after a foreign divestment happened are included to test how persistent the effects may be. ${ }^{48}$ Last but not least, in an alternative specification, heterogeneous effects of divestment on outcomes are allowed across groups of firms (e.g., financial, industrial, individual investors; small and large firms):

$$
\ln X_{f s c t}=\sum_{j=1}^{J} \alpha_{j} \Theta_{j} D_{f s c t}+\sum_{j=1}^{J} \Theta_{j(-1)}+\lambda_{s c t}+\varepsilon_{f s c t}(2)
$$

where $\Theta=\left\{\Theta_{1}, \ldots, \Theta_{J}\right\}$ is a set of binary indicators that identify the group of firms.

In the case of foreign acquisitions, the estimating equation is the same as in (1) whereby D refers to foreign acquisitions, instead of foreign divestments, and the comparison group become firms that have been domestic-owned at the beginning of the sample period, 2007, and have never been acquired. Similarly, in the case of regressions on the relationship between foreign ownership and performance, the estimating equation is also (1) whereby D refers to a binary variable when a firm is foreign-owned. Firm fixed effects are included in one alternative specification (not reported).

\footnotetext{
48 The results for these exercise are not reported here but are available upon request.
} 
Table B.1. Estimation results: Foreign divestments and acquisitions and performance of affiliates

Panel A. Foreign Divestments

\begin{tabular}{|c|c|c|c|c|c|c|c|}
\hline & (1) & (2) & (3) & (4) & (5) & (6) & (7) \\
\hline & $\begin{array}{l}\text { Sales } \\
(\log )\end{array}$ & $\begin{array}{r}\text { Employees } \\
(\log )\end{array}$ & $\begin{array}{r}\text { Value- } \\
\text { added } \\
(\log )\end{array}$ & $\begin{array}{r}\text { Turnover } \\
\text { per } \\
\text { employee } \\
(\log )\end{array}$ & $\begin{array}{r}\text { Value- } \\
\text { added per } \\
\text { employee } \\
(\log )\end{array}$ & $\begin{array}{r}\mathrm{ROA} \\
(\log )\end{array}$ & $\begin{array}{l}\text { Liquidity } \\
\text { ratio (log) }\end{array}$ \\
\hline \multirow{2}{*}{$\begin{array}{r}\text { Foreign } \\
\text { Divestment }\end{array}$} & $-0.281 * * *$ & $-0.132 * *$ & $-0.244 * * *$ & $-0.147 * * *$ & $-0.112 * * *$ & -0.0312 & 0.0112 \\
\hline & $(0.0514)$ & $(0.0450)$ & $(0.0476)$ & $(0.0295)$ & $(0.0262)$ & $(0.0346)$ & $(0.0365)$ \\
\hline \multirow{2}{*}{$\begin{array}{l}\text { Foreign-to- } \\
\text { foreign sale }\end{array}$} & $0.155 * * *$ & $0.105 * * *$ & $0.137 * * *$ & $0.0430 * *$ & $0.0316^{* *}$ & 0.00240 & 0.0240 \\
\hline & $(0.0243)$ & $(0.0214)$ & $(0.0221)$ & $(0.0134)$ & $(0.0106)$ & $(0.0139)$ & $(0.0128)$ \\
\hline Observations & 91215 & 91215 & 91215 & 91215 & 91215 & 91215 & 91215 \\
\hline R-squared & 0.548 & 0.426 & 0.546 & 0.596 & 0.600 & 0.201 & 0.206 \\
\hline $\begin{array}{r}\text { Country-year- } \\
\text { sector fixed } \\
\text { effects }\end{array}$ & YES & YES & YES & YES & YES & YES & YES \\
\hline
\end{tabular}

Panel B. Foreign Acquisitions

\begin{tabular}{|c|c|c|c|c|c|c|c|}
\hline & (1) & (2) & (3) & (4) & (5) & (6) & (7) \\
\hline & Sales $(\log )$ & $\begin{array}{r}\text { Employee } \\
\text { s (log) }\end{array}$ & $\begin{array}{r}\text { Value- } \\
\text { added } \\
(\log )\end{array}$ & $\begin{array}{r}\text { Turnover } \\
\text { per } \\
\text { employee } \\
(\log )\end{array}$ & $\begin{array}{r}\text { Value-added } \\
\text { per } \\
\text { employee } \\
(\log )\end{array}$ & $\begin{array}{r}\text { ROA } \\
(\log )\end{array}$ & $\begin{array}{r}\text { Liquidity } \\
\text { ratio (log) }\end{array}$ \\
\hline \multirow{2}{*}{$\begin{array}{r}\text { Foreign } \\
\text { Acquisition }\end{array}$} & $1.219 * * *$ & $0.910 * * *$ & $1.168 * * *$ & $0.303 * * *$ & $0.259 * * *$ & $0.0522 *$ & -0.0354 \\
\hline & $(0.0403)$ & $(0.0364)$ & $(0.0379)$ & $(0.0219)$ & $(0.0195)$ & $\begin{array}{r}(0.0248 \\
)\end{array}$ & $(0.0225)$ \\
\hline \multirow{2}{*}{$\begin{array}{l}\text { Domestic-to- } \\
\text { domestic sale }\end{array}$} & $0.629 * * *$ & $0.483 * * *$ & $0.602 * * *$ & $0.150 * * *$ & $0.118 * * *$ & 0.00733 & $-0.0416^{* * *}$ \\
\hline & $(0.0132)$ & $(0.0116)$ & $(0.0124)$ & $(0.00686)$ & $(0.00594)$ & $\begin{array}{r}(0.0073 \\
8)\end{array}$ & $(0.00772)$ \\
\hline Observations & 701958 & 701958 & 701958 & 701958 & 701958 & 701958 & 701958 \\
\hline R-squared & 0.568 & 0.393 & 0.579 & 0.646 & 0.662 & 0.206 & 0.171 \\
\hline $\begin{array}{r}\text { Country-year- } \\
\text { sector fixed } \\
\text { effects }\end{array}$ & YES & YES & YES & YES & YES & YES & YES \\
\hline
\end{tabular}

Note: Stars denote statistical significance at: $* * * 99 \%, * * 95 \%, * 90 \%$ respectively. Turnover per employee is calculated as OPR_TURNOVER/ NUMBER_OF_EMPLOYEES, return on assets (ROA) as EBITDA/TOTAL_ASSETS and the liquidity ratio as (CURRENT_ASSETS)/ CURRENT_LIABILITIES. Robust standard errors are reported in parenthesis and are clustered by firm. The country-year-sector fixed effects included in the estimation are at 4-digit level (NAICS classification). Panel A shows a comparison of previously foreign-owned firms that were sold by their foreign parents to domestic investors to other foreign-owned firms; while Panel B shows a comparison of previously domesticowned firms that were acquired by foreign parents from domestic investors to other domestic owned firms.

Source: Authors calculations using ORBIS $($ ) data. 
Table B.2. Estimation results: Foreign divestments and performance of affiliates firmsHeterogeneous effects according to the affiliate firm size

\begin{tabular}{|c|c|c|c|c|c|c|c|}
\hline & (1) & (2) & (3) & (4) & (5) & (6) & (7) \\
\hline & $\begin{array}{r}\text { Sales } \\
(\log )\end{array}$ & $\begin{array}{r}\text { Employees } \\
(\log )\end{array}$ & $\begin{array}{r}\text { Value-added } \\
(\log )\end{array}$ & $\begin{array}{r}\text { Turnover per } \\
\text { employee (log) }\end{array}$ & $\begin{array}{r}\text { Value-added per } \\
\text { employee (log) }\end{array}$ & $\begin{array}{r}\text { ROA } \\
(\log )\end{array}$ & $\begin{array}{r}\text { Liquidity } \\
\text { ratio (log) }\end{array}$ \\
\hline \multirow[t]{2}{*}{ DivestmentxMicrofirms } & -0.108 & 0.0535 & 0.0352 & -0.143 & -0.0183 & 0.0472 & 0.114 \\
\hline & $(0.0845)$ & $(0.0462)$ & $(0.0764)$ & $(0.0778)$ & $(0.0705)$ & $(0.0792)$ & $(0.0950)$ \\
\hline \multirow[t]{2}{*}{ DivestmentxSMEs } & $-0.160^{\star * \star}$ & -0.00191 & $-0.178^{\star \star *}$ & $-0.162^{\star \star \star}$ & $-0.176^{* * *}$ & -0.0469 & -0.0313 \\
\hline & $(0.0431)$ & $(0.0312)$ & $(0.0397)$ & $(0.0323)$ & $(0.0268)$ & $(0.0415)$ & $(0.0395)$ \\
\hline \multirow[t]{2}{*}{ DivestmentxLarge firms } & -0.171 & -0.0354 & -0.0741 & $-0.139^{*}$ & -0.0387 & -0.108 & -0.0689 \\
\hline & $(0.0885)$ & $(0.0669)$ & $(0.0911)$ & $(0.0594)$ & $(0.0621)$ & $(0.0891)$ & $(0.0734)$ \\
\hline \multirow{2}{*}{ Foreign-to-foreign sale } & $0.0725^{\star * *}$ & 0.0179 & $0.0655^{* * *}$ & $0.0525^{* * *}$ & $0.0476^{* * *}$ & 0.00354 & $0.0319^{*}$ \\
\hline & $(0.0174)$ & $(0.0114)$ & $(0.0148)$ & $(0.0135)$ & $(0.0106)$ & $(0.0139)$ & $(0.0126)$ \\
\hline \multirow[t]{2}{*}{ Micro firms } & $-4.439^{\star * *}$ & $-4.702^{\star \star *}$ & $-4.284^{* * *}$ & $0.292^{\star \star *}$ & $0.418^{* \star *}$ & $-0.0624^{*}$ & $0.346^{* * *}$ \\
\hline & $(0.0381)$ & $(0.0229)$ & $(0.0316)$ & $(0.0310)$ & $(0.0239)$ & $(0.0253)$ & $(0.0259)$ \\
\hline \multirow[t]{2}{*}{ SMEs } & $-2.239^{\star * *}$ & $-2.364^{* \star *}$ & $-2.226^{\star \star *}$ & $0.126^{\star * *}$ & $0.137^{\star \star \star *}$ & 0.0251 & $0.196^{* * *}$ \\
\hline & $(0.0278)$ & $(0.0193)$ & $(0.0237)$ & $(0.0205)$ & $(0.0150)$ & $(0.0182)$ & $(0.0172)$ \\
\hline Observations & 91215 & 91215 & 91215 & 91215 & 91215 & 91215 & 91215 \\
\hline R-squared & 0.761 & 0.831 & 0.783 & 0.599 & 0.608 & 0.201 & 0.212 \\
\hline $\begin{array}{r}\text { Country-year-sector fixed } \\
\text { effects }\end{array}$ & YES & YES & YES & YES & YES & YES & YES \\
\hline
\end{tabular}

Note: Stars denote statistical significance at: $* * * 99 \%, * * 95 \%, * 90 \%$ respectively. Turnover per employee is calculated as OPR_TURNOVER/NUMBER_OF_EMPLOYEES, return on assets (ROA) as EBITDA/TOTAL_ASSETS and the liquidity ratio as (CURRENT_ASSETS)/ CURRENT_LIABILITIES. Robust standard errors are reported in parenthesis and are clustered by firm. The country-year-sector fixed effects included in the estimation are at 4-digit level (NAICS classification). Following the standard OECD statistical definition, micro firms refer to firms that have less than 10 employees, small- and medium-sized firms (SMEs) to firms that have between 10 and 249 employees and large firms to those with more than 250 employees.

Source: OECD calculations using ORBIS $\odot$ data. 
Table B.3. Estimation results: Foreign divestments and performance of affiliates FirmsHeterogeneous effects according to the type of parent firm

\begin{tabular}{|c|c|c|c|c|c|c|c|}
\hline & (1) & (2) & (3) & (4) & (5) & (6) & (7) \\
\hline & $\begin{array}{r}\text { Sales } \\
(\log )\end{array}$ & $\begin{array}{r}\text { Employees } \\
(\log )\end{array}$ & $\begin{array}{r}\text { Value- } \\
\text { added (log) }\end{array}$ & $\begin{array}{r}\text { Turnover per } \\
\text { employee (log) }\end{array}$ & $\begin{array}{r}\text { Value-added per } \\
\text { employee (log) }\end{array}$ & $\begin{array}{r}\mathrm{ROA} \\
(\log )\end{array}$ & $\begin{array}{r}\text { Liquidity } \\
\text { ratio (log) }\end{array}$ \\
\hline \multirow[t]{2}{*}{ DivestmentxFinancial } & -0.0914 & 0.0339 & -0.0655 & -0.129 & -0.0993 & -0.134 & 0.157 \\
\hline & $(0.137)$ & $(0.122)$ & $(0.130)$ & $(0.0876)$ & $(0.0806)$ & $(0.105)$ & $(0.112)$ \\
\hline \multirow{2}{*}{$\begin{array}{r}\text { DivestmentxIndustrial and } \\
\text { other }\end{array}$} & $-0.231^{* * *}$ & -0.111 & $-0.211^{* * *}$ & $-0.128^{* * *}$ & $-0.101^{* * *}$ & $-0.0929^{*}$ & -0.0218 \\
\hline & $(0.0632)$ & $(0.0576)$ & $(0.0585)$ & $(0.0356)$ & $(0.0300)$ & $(0.0422)$ & $(0.0379)$ \\
\hline \multirow[t]{2}{*}{ DivestmentxIndividual } & $-0.296^{* *}$ & -0.137 & $-0.226^{*}$ & $-0.133^{*}$ & -0.0892 & $0.151^{*}$ & 0.0166 \\
\hline & $(0.101)$ & $(0.0845)$ & $(0.0930)$ & $(0.0617)$ & $(0.0575)$ & $(0.0717)$ & $(0.0908)$ \\
\hline \multirow[t]{2}{*}{ Foreign-to-foreign sale } & $0.123^{\star \star *}$ & $0.0817^{\star * *}$ & $0.115^{\star * *}$ & $0.0385^{\star *}$ & $0.0329^{* *}$ & 0.00685 & $0.0269^{*}$ \\
\hline & $(0.0238)$ & $(0.0212)$ & $(0.0217)$ & $(0.0134)$ & $(0.0106)$ & $(0.0139)$ & $(0.0127)$ \\
\hline \multirow[t]{2}{*}{ Financial } & $0.886^{\star \star *}$ & $0.552^{\star \star \star}$ & $0.792^{\star \star *}$ & $0.323^{\star * *}$ & $0.240^{\star * *}$ & -0.0420 & 0.0139 \\
\hline & $(0.0546)$ & $(0.0476)$ & $(0.0505)$ & $(0.0305)$ & $(0.0255)$ & $(0.0266)$ & $(0.0294)$ \\
\hline \multirow[t]{2}{*}{ Industrial and other } & $1.096^{* \star *}$ & $0.716^{\star \star \star}$ & $1.003^{* * *}$ & $0.371^{\star \star *}$ & $0.287^{\star \star *}$ & $0.0531^{-}$ & 0.0323 \\
\hline & $(0.0402)$ & $(0.0344)$ & $(0.0374)$ & $(0.0206)$ & $(0.0173)$ & $(0.0187)$ & $(0.0218)$ \\
\hline Observations & 91215 & 91215 & 91215 & 91215 & 91215 & 91215 & 91215 \\
\hline R-squared & 0.570 & 0.442 & 0.568 & 0.603 & 0.605 & 0.201 & 0.206 \\
\hline $\begin{array}{r}\text { Country-year-sector fixed } \\
\text { effects }\end{array}$ & YES & YES & YES & YES & YES & YES & YES \\
\hline
\end{tabular}

Note: Stars denote statistical significance at: $* * * 99 \%, * * 95 \%, * 90 \%$ respectively. Turnover per employee is calculated as OPR_TURNOVER/ NUMBER_OF_EMPLOYEES, return on assets (ROA) as EBITDA/TOTAL_ASSETS and the liquidity ratio as (CURRENT_ASSETS)/ CURRENT_LIABILITIES. Robust standard errors are reported in parenthesis and are clustered by firm. The country-year-sector fixed effects included are at 4-digit level (NAICS classification). An investor is considered a financial investor if its legal entity type is an insurance company, a bank, a mutual fund, pension fund, a trust, a nominee, a financial company, a private equity firm, a venture capital fund or a hedge fund. An investor is considered to be an industrial company if its legal entity type is an industrial company (state-owned enterprises are also included in this category). An investor is considered an individual investor if its legal entity is self-ownership, individual(s) or family(ies), foundation or research Institute, employees/managers/directors, unnamed private shareholders or other unnamed shareholders.

Source: OECD calculations using ORBIS $\odot$ data. 


\title{
Annex C. OECD Working Papers on International Investment
}

\author{
www.oecd.org/investment/working-papers.htm
}

\section{9}

2019/02 The broad policy toolkit for financial stability: Foundations, fences, and fire doors

2019/01 The determinants of Foreign Direct Investment protection and the right to regulate in investment treaties: A scoping paper

\section{8}

2018/1 Societal benefits and costs of International Investment Agreements: A critical review of aspects and available empirical evidence

\section{7}

2017/5 Adjudicator Compensation Systems and Investor-State Dispute Settlement

2017/4 Have currency-based capital flow management measures curbed international banking flows?

2017/3 Addressing the balance of interests in investment treaties: The limitation of fair and equitable treatment provisions to the minimum standard of treatment under customary international law

2017/2 The balance between investor protection and the right to regulate in investment treaties: A scoping paper

2017/1 Foreign direct investment, corruption and the OECD Anti-Bribery Convention

\section{6}

2016/3 State-to-State dispute settlement and the interpretation of investment treaties

2016/2 Investment policies related to national security

2016/1 The legal framework applicable to joint interpretive agreements of investment treaties

\section{5}

2015/3 Currency-based measures targeting banks - Balancing national regulation of risk and financial openness

2015/2 Investment Treaties over Time - Treaty Practice and Interpretation in a Changing World

2015/1 The Policy Landscape for International Investment by Government-controlled Investors: A Fact Finding Survey

\section{4}

2014/3 Investment Treaties and Shareholder Claims: Analysis of Treaty Practice 
2014/2 Investment Treaties and Shareholder Claims for Reflective Loss: Insights from Advanced Systems of Corporate Law

2014/1 Investment Treaty Law, Sustainable Development and Responsible Business Conduct: A Fact Finding Survey

\section{3}

2013/4 Temporal validity of international investment agreements: a large sample survey of treaty provisions

2013/3 Investment treaties as corporate law: Shareholder claims and issues of consistency

2013/2 Lessons from Investment Policy Reform in Korea

2013/1 China Investment Policy: an Update

\section{2}

2012/3 Investor-state dispute settlement: A scoping paper for the investment policy community 2012/2 Dispute settlement provisions in international investment agreements: A large sample survey 2012/1 Corporate greenhouse gas emission reporting: A stocktaking of government schemes

\section{1}

2011/2 Defining and measuring green FDI: An exploratory review of existing work and evidence 2011/1 Environmental concerns in international investment agreements: a survey

2010

2010/3 OECD's FDI Restrictiveness Index: 2010 Update

2010/2 Foreign state immunity and foreign government controlled investors

2010/1 Intellectual property rights in international investment agreements

\section{6}

2006/4 OECD's FDI regulatory restrictiveness index: Revision and extension to more economies 2006/3 Interpretation of the Umbrella Clause in Investment Agreements

2006/2 Investor-State Dispute Settlement in Infrastructure Projects

2006/1 Improving the System of Investor-State Dispute Settlement: An Overview

\section{5}

2005/3 Corporate Responsibility Practices of Emerging Market Companies - A Fact-Finding Study 2005/2 Multilateral Influences on the OECD Guidelines for Multinational Enterprises 2005/1 Transparency and Third Party Participation in Investor-State Dispute Settlement Procedures 2004

2004/6 Mobilising Investment for Development: Role of ODA - The 1993-2003 Experience in Vietnam 
2004/5 ODA and Investment for Development: What Guidance can be drawn from Investment Climate Scoreboards?

2004/4 Indirect Expropriation and the Right to Regulate in International Investment Law

2004/3 Fair and Equitable Treatment Standard in International Investment Law

2004/2 Most-Favoured-Nation Treatment in International Investment Law

2004/1 Relationships between International Investment Agreements

\section{3}

2003/2 Business Approaches to Combating Corrupt Practices

2003/1 Incentives-based Competition for Foreign Direct Investment: The Case of Brazil

2002

2002/2 Managing Working Conditions in the Supply Chain: A Fact-Finding Study of Corporate Practices 2002/1 Multinational Enterprises in Situations of Violent Conflict and Widespread Human Rights Abuses

2001

2001/6 Codes of Corporate Conduct: Expanded review of their contents

2001/5 The OECD Guidelines for Multinational Enterprises and other corporate responsibility instruments 2001/4 Public policy and voluntary initiatives: What roles have governments played?

2001/3 Making codes of corporate conduct work: Management control systems and corporate responsibility

2001/2 Corporate Responsibility: Results of a fact-finding mission on private initiatives

2001/1 Private Initiatives for Corporate Responsibility: An Analysis

2000

2000/5 Recent trends, policies and challenges in South East European countries

2000/4 Main determinants and impacts of FDI on China's economy

2000/3 Lithuania: Foreign Direct Investment Impact and Policy Analysis

2000/2 Investment Patterns in a Longer-Term Perspective

2000/1 Bribery and the business sector: Managing the relationship

1999

1999/3 Rules for the Global Economy: Synergies between Voluntary and Binding Approaches

1999/2 Deciphering Codes of Corporate Conduct: A Review of their Contents

1999/1 Southeast Asia: the Role of FDI Policies in Development

1998

1998/1 Survey of OECD work on international investment 